\title{
Seasonal Variability in In-situ Supraglacial Streamflow and Drivers in Southwest Greenland in 2016
}

\author{
Rohi Muthyala $^{1}$, Asa K. Rennermalm ${ }^{1}$, Sasha Z. Leidman ${ }^{1}$, Matthew G. Cooper ${ }^{2}$, Sarah W. Cooley ${ }^{3,4}$,
} Laurence C. Smith ${ }^{3,4}$, Dirk van $\mathrm{As}^{5}$

$5 \quad{ }^{1}$ Department of Geography, Rutgers, The State University of New Jersey, New Brunswick, NJ, 08901, USA

${ }^{2}$ Atmospheric Sciences and Global Change Division, Pacific Northwest National Laboratory, Richland, WA, 99354, USA

${ }^{3}$ Institute at Brown for Environment and Society, Brown University, Providence, RI, 02912, USA

${ }^{4}$ Department of Earth, Environmental, and Planetary Sciences, Brown University, Providence, RI, 02912, USA

${ }^{5}$ Geological Survey of Denmark and Greenland, Øster Voldgade 10, 1350 Copenhagen, Denmark

10 Correspondence to: Rohi Muthyala (rohi.muthyala.91@gmail.com)

\begin{abstract}
Greenland ice sheet surface runoff is evacuated through supraglacial stream networks, which influence surface mass balance as well as ice dynamics. However, in-situ observations of meltwater discharge through these stream networks are rare. In this study, we present 46 discharge measurements and continuous water level measurements for 62 days spanning 13 June to 13 August 2016 for a $0.6 \mathrm{~km}^{2}$ supraglacial stream catchment in southwest Greenland. The result is an unprecedented long record of supraglacial discharge capturing both diurnal and seasonal variability. By comparing in situ hydraulic geometry parameters with previous studies, we find that significant heterogeneity exists such that estimating stream discharge using these parameters over ungauged supraglacial catchments could lead to substantial errors. A comparison of surface energy fluxes to stream discharge reveals shortwave radiation as the primary driver of melting (78\% of melt energy). However, during high melt episodes, the shortwave only contributes to $50 \%$ of melt energy. Instead, the relative contribution of longwave 20 radiation, sensible and latent heat fluxes to overall melt increases by $16.5 \%, 4 \%$, and $7 \%$ respectively. Our data also show a seasonal variation in the timing of daily maximum discharge during clear sky days, shifting from 16:00 local time (i.e., 2.75 hours after solar noon) in late June to 14:00 in late July, then rapidly returns to 16:00 in early August coincident with an abrupt drop in air temperature. These changes in peak daily flow timing can be attributed to a changing effective catchment area, resulting in a smaller stream network supplying water to the outlet at the end of the season throughout the melt season. Further work is needed to uncover how widespread rapid shift in the timing of peak discharge is across Greenland supraglacial streams, and thus their potential impact on meltwater delivery to the subglacial system and ice dynamics.
\end{abstract}


https://doi.org/10.5194/tc-2020-314

Preprint. Discussion started: 27 November 2020

(c) Author(s) 2020. CC BY 4.0 License.

(c) (i)

\section{Introduction}

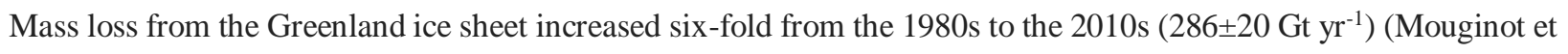

30 al., 2019; Shepherd et al., 2019; Velicogna et al., 2020). This mass loss was dominated by enhanced surface melting and runoff (Van den Broeke et al., 2016). The increase in runoff raised Greenland's contribution to global sea-level rise from less than 5\% in 1993 to more than 25\% in 2014 (Chen et al., 2017). Increased surface melting also influences ice sheet basal properties (Das et al., 2008; Colgan et al., 2011; Bell et al., 2017; Kingslake et al., 2017; Flowers, 2018), and ice dynamics (Van de Wal et al., 2008; Shepherd et al., 2009; Schoof, 2010; Hoffmann et al., 2011; Hewitt, 2013; Andrews et al., 2015). Despite the

35 importance of Greenland's surface runoff to surface mass balance and sea level rise, only a handful of studies using in situ supraglacial stream discharge to characterize current conditions (Holmes, 1955; Chandler et al., 2013; McGrath et al., 2011; Smith et al., 2015; Gleason et al., 2016; Smith et al., 2017), and these studies are limited to short periods (a couple of days to a maximum of 15 days).

Every melting season, numerous supraglacial stream/river drainage networks develop on the surface of the Greenland

40 ice sheet ablation zone (Smith et al., 2015; 2017; Yang and Smith, 2013; 2016; Pitcher and Smith, 2019). These networks transport runoff sourced from melting ice, snow, and/or slush within the stream catchment (Holmes, 1955; Karlstrom et al., 2014), and often terminate in moulins, from where meltwater moves within and beneath the ice sheet before emerging in proglacial rivers, lakes, fjords, and the ocean (Chu, 2014; Rennermalm et al., 2013).

Supraglacial stream discharge varies seasonally in concert with surface melting, with low flow in the beginning and

45 end of the melting season and higher flow in the middle of the melting season (Holmes, 1955). Supraglacial discharge also shows a pronounced diurnal variation (McGrath et al., 2011; Smith et al., 2017; Yang et al., 2018). While daily maximum discharge varies with catchment size and day of the season, discharge decreases when melt energy drops off at night (Marston et al., 1983; Mernild et al., 2006; McGrath et al., 2011; Yang et al., 2018). Diurnal variability and timing of meltwater delivery to the subglacial drainage system have been shown to influence ice sheet velocities in several studies (Bartholomew et al.,

50 2012; Andrews et al., 2014; Smith et al., 2020).

The routing of meltwater through supraglacial stream networks delays the timing of peak discharge at the moulin relative to the timing of peak surface melt (Karlstrom et al., 2014; Yang et al., 2018). This peak time lag depends on the size of the catchment and meltwater routing time (Holmes, 1955; Mernild et al., 2006; McGrath et al., 2011; Smith et al., 2017). Larger catchments imply a longer stream network, and thus a larger time lag. Additionally, the seasonal evolution of a

55 supraglacial stream network can alter the magnitude and timing of peak moulin discharge. For example, as the actively flowing network contracts through the season (Lampkin and VanderBerg, 2014), the time lag increases, and the magnitude of moulin discharge decreases (Yang et al., 2018). The magnitude and timing of peak moulin discharge may also be influenced by the temporary storage of meltwater in the weathering crust (Cooper et al., 2018). Weathering crust is a degraded, porous surface 
https://doi.org/10.5194/tc-2020-314

Preprint. Discussion started: 27 November 2020

(c) Author(s) 2020. CC BY 4.0 License.

\section{(c) (i)}

layer of ice that retains meltwater temporarily and promotes subsurface flow (Karlstrom et al., 2014; Cooper et al., 2018), and

In Greenland's ablation zone, the seasonal and interannual variability in meltwater production, thereby surface runoff, is primarily driven by the variability of the absorption of shortwave radiation (Van den Broeke et al., 2011). Secondary melt drivers are turbulent fluxes of sensible and latent heat, particularly in the lower ablation zone of southwest Greenland (Van den Broeke et al., 2011, Fausto et al. 2016). Additional drivers are anomalously moist and warm air masses advected over the ice sheet by atmospheric rivers (Mattingly et al., 2018), and clouds with contrasting feedback to surface melt (Bennartz et al., 2013). While an increase in cloud cover enhances downward longwave radiation and hence melt (Van Tricht et al., 2016; Gallagher et al., 2020; Izeboud et al., 2020), it also limits the shortwave radiation thus decreasing summer melt in ablation areas (Hofer et al., 2017; Izeboud et al., 2020). Numerous studies examine the linkages between surface energy balance, surface melting, and runoff using regional climate models (Fettweis et al., 2017; Noel et al., 2018), and automatic weather station data

70 (van As et al., 2012), but relatively few compare surface energy fluxes with in situ observations of supraglacial stream discharge in Greenland (Smith et al., 2017).

Smith et al. (2015) and Gleason et al., (2016), examine how Greenland supraglacial streams can be characterized with hydraulic geometry principles. In terrestrial hydrology, at-a-station hydraulic geometry theory holds that channel width, depth, and velocity co-vary nonlinearly with discharge for a fixed stream cross-section (Leopold and Maddock, 1953; Gleason et al.,

75 2015). This theory provides a set of equations with parameters that can be generalized to estimate discharge in ungauged rivers (Smith et al., 1996; 2015; Ashmore and Sauks, 2006; Andreadis et al., 2020). Similarly, a generalization of supraglacial streams' hydraulic geometries would open possibilities for scaling and modeling discharge. For example, Smith et al. (2015) used field-calibrated hydraulic geometry to estimate instantaneous discharges in 523 moulins in southwestern Greenland, yielding values ranging from 0.36 to $17.72 \mathrm{~m}^{3} \mathrm{~s}^{-1}$ with a mean value of $3.15 \mathrm{~m}^{3} \mathrm{~s}^{-1}$. In contrast, Gleason et al. (2016) and Smith

80 et al. (2017) argued that unlike terrestrial systems, uniform hydraulic behavior cannot be expected from an ice substrate. However, only a few studies have quantified hydraulic geometry of supraglacial streams.

In this study, we present a 62-day time series of supraglacial streamflow, in southwest Greenland, spanning most of the 2016 melting season in terms of total meltwater production. The supraglacial stream drainage network was mapped using unmanned aerial vehicle (UAV) imagery and manual GPS observations, and surface energy fluxes were calculated or measured using meteorological observations from a nearby automatic weather station. Using these data, we examine supraglacial discharge uncertainties, covariance between discharge and surface energy balance drivers, seasonal changes in daily peak discharge timing, and hydraulic geometry parameters. Finally, we compare our hydraulic geometry parameters to previous work on supraglacial streams. 
https://doi.org/10.5194/tc-2020-314

Preprint. Discussion started: 27 November 2020

(c) Author(s) 2020. CC BY 4.0 License.

(c) (i)

\section{Study Area}

The study area is a $0.6 \mathrm{~km}^{2}$ internally drained supraglacial catchment in southwest Greenland, hereafter called ' 660 catchment' (after "Point 660" where a gravel road ends at the ice sheet margin). The catchment is located $\sim 1-2 \mathrm{~km}$ upstream of the ice edge between two outlet glaciers, Isunnguata Sermia and Russell Glacier, and roughly $35 \mathrm{~km}$ east of the town of Kangerlussuaq (Fig. 1). The stream network terminates in a moulin $\left(67.1562^{\circ} \mathrm{N}, 50.0064^{\circ} \mathrm{W}\right)$. About $850 \mathrm{~m}$ upstream of the moulin, a gauging station for monitoring water level and discharge was installed at $67.1573^{\circ} \mathrm{N}, 49.9951^{\circ} \mathrm{W}$. Elevations in the catchment span from $610 \mathrm{~m}$ near the gauging station to $660 \mathrm{~m}$ (above the WGS84 ellipsoid) at the catchment's highest point (Fig. 1).

The catchment surface consists of a rugged bare-ice landscape with small supraglacial ponds and an incised stream network (Fig. 2a). The clean bare-ice surface with minimal impurities has an albedo of $0.57 \pm 0.04$ (Moustafa et al., 2015) and had a thin $(\sim 0.1-0.3 \mathrm{~m})$ surface layer of weathering crust comprising porous ice and cryoconite holes (Fig. 2c). These cryoconite holes are partially filled with water and accumulate "cryoconite," consisting of dust, sediment, and biological matter (Takeuchi et al., 2000; Cooper et al., 2019). Cryoconite deposits are widespread in streams and ponds throughout the catchment. The catchment is situated in a region where winter snow accumulation is relatively low, and that experiences extensive melting from June through August so that little to no snow cover remains on the bare ice early in the melting season (Rennermalm et al., 2013; Ryan et al., 2019).

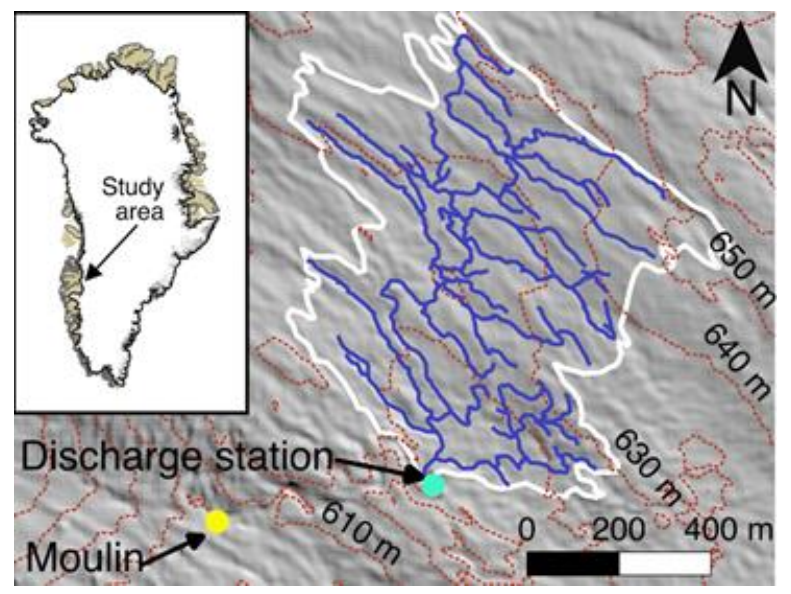

Figure 1: Map of study site showing the supraglacial catchment boundary (white), streams of order 1, 2, and 3 (blue), and locations of the discharge station and the moulin. Red contour lines are derived using a $10 \mathrm{~m}$ Arctic DEM from Polar Geospatial Center (PGC). Hillshading is generated from a PGC 2m DEM.

\section{Data and methods}

\subsection{Supraglacial stream discharge}

Supraglacial stream discharge was calculated for 62 days from 13 June to 13 August 2016. Discharge was determined with a rating curve relating 46 occasional discharge measurements to continuous ( 5 min interval) observations of stream water 
stage. Stream water stage was measured every 5 min using a setup of two Solinst loggers (pressure transducers), a Levelogger in a weighted steel enclosure resting on the stream bed tied to a pole (Fig. 2b) and a Barologger (Solinst, 2020) installed 25-

$11530 \mathrm{~m}$ northeast of the gauging station. Stage is calculated after barometric pressure correction.
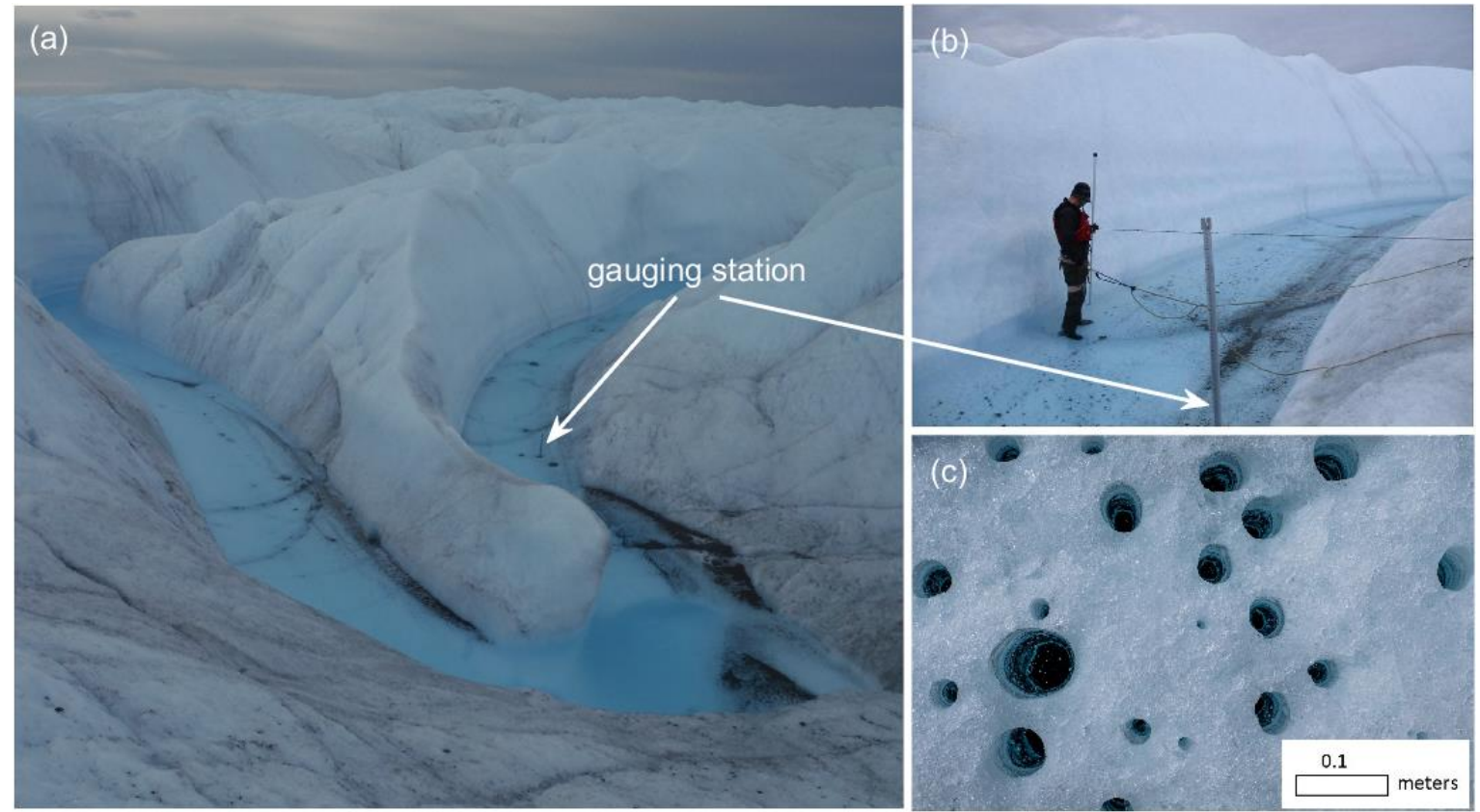

Figure 2: (a) The main stem of the supraglacial stream, and location of the gauging station. (b) Close up photo of the stream crosssection, and the gauging station during discharge measurement. (c) Cryoconite holes on the bare ice surface vary from $0.02-0.08 \mathrm{~m}$ in diameter and $0.1-0.3 \mathrm{~m}$ in depth (in this figure). These holes are partially water filled and contain cryoconite (biological matter), dust, and sediment at the bottom.

Discharge was calculated with the velocity-area method using inputs of cross-sectional area and stream water velocity (e.g. Herschy, 1993a). In total, 46 observations of velocity and cross-sectional area were made, including 27 measured every hour from 15:30 on 26 July 2016 to 17:30 on 27 July 2016 (local time) to capture the entire diurnal range. The remaining 19 observations were collected over the entire study period and sampled on average every 3-7 days between 12:00 to 17:00 local time. Cross-sections of stream depth were measured at $0.2 \mathrm{~m}$ intervals across the 1.7-3.3 $\mathrm{m}$ wide stream. Though measurements were collected in the same location throughout the season, continuous thermal erosion of the bed resulted in small changes in cross-sectional geometry (Fig. 3a). Stream velocity was measured at each $0.2 \mathrm{~m}$ interval at $60 \%$ of the depth, with either a General Oceanics current meter or Price Type-AA current meter.

The discharge rating curve was generated with a best fit power-law (e.g. Herschy, 1993b):

$$
Q=p(H+\alpha)^{\beta}
$$


https://doi.org/10.5194/tc-2020-314

Preprint. Discussion started: 27 November 2020

(c) Author(s) 2020. CC BY 4.0 License.

(c) (i)

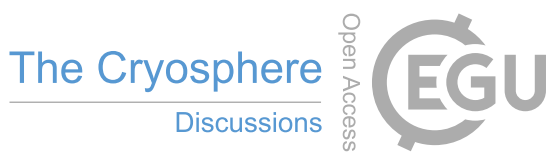

where $\mathrm{p}$ and $\beta$ are constants estimated by fitting the curve to observations of discharge $(\mathrm{Q})$ and water level, also called stage height $(\mathrm{H})$, and $\alpha$ is the water level sensor offset from the stream bottom. In this study, the box with the level logger was placed on the stream bed and therefore $\alpha=0$.
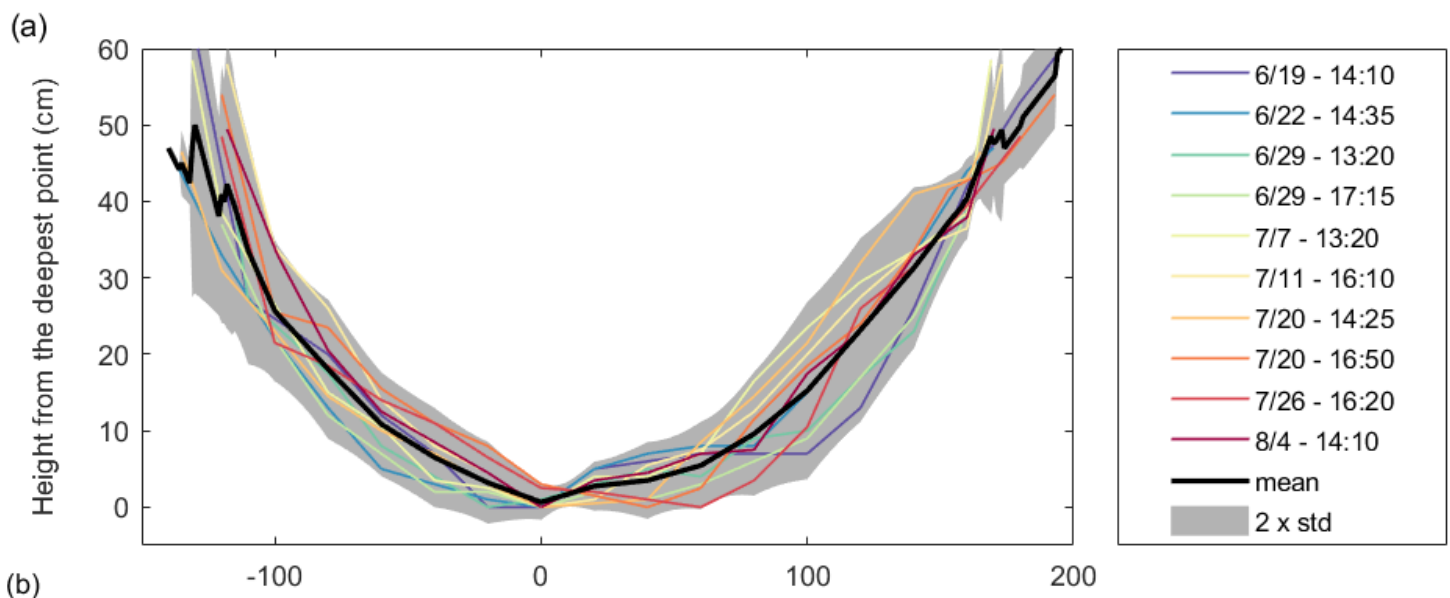

(b)
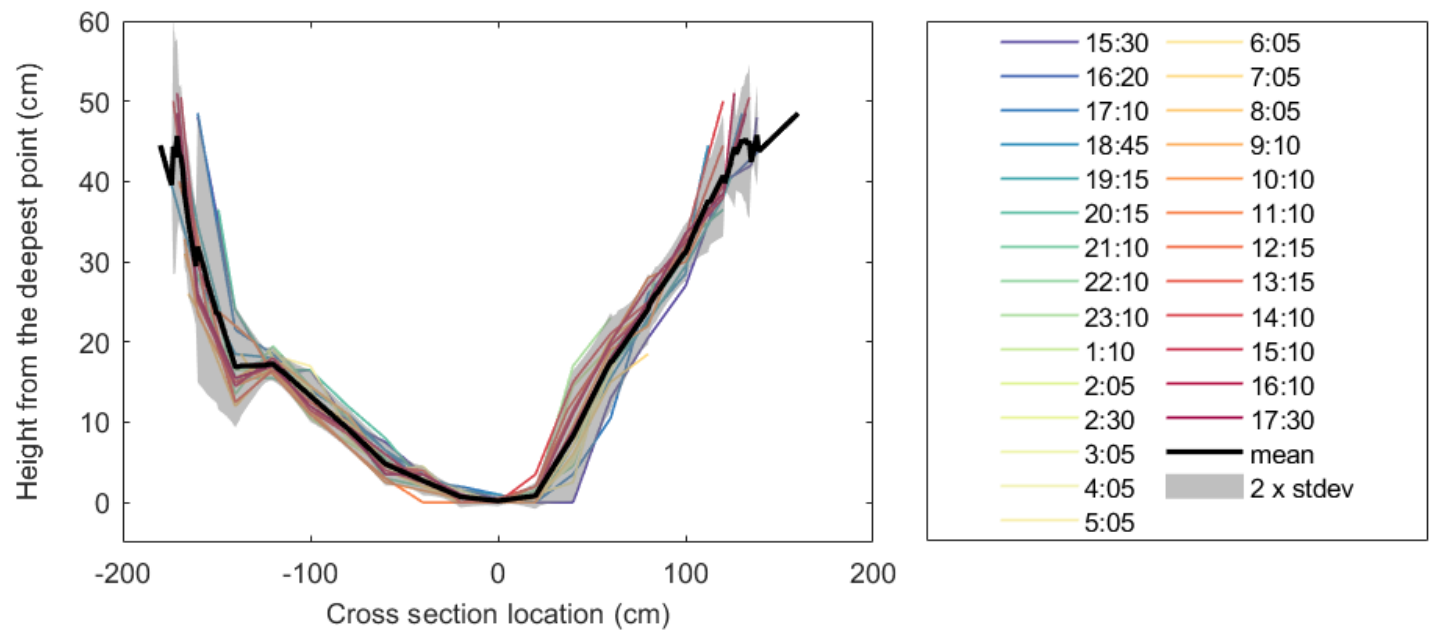

135 Figure 3: Stream cross-section depth profiles: (a) daily cross-sections using measurements performed during 19 June through 8 August, with samples collected on average every 3-7 days, and (b) hourly cross-sections using measurements from 15:30 on 26 July to 17:30 on 27 July 2016; These depth profiles are made with the maximum depth as a point of reference in each sample. The mean profile is shown in a thick black line and uncertainty ( 2 standard deviation) is shown in the grey shaded area. All times correspond to local time.

The rating curve $\left(\mathrm{Q}=3.925 \mathrm{H}^{2.44}, \mathrm{R}^{2}=0.94\right)$ was then used to generate continuous discharge values from stage measurements recorded every $5 \mathrm{~min}$ throughout the season. These data were in turn averaged to yield hourly discharge data (Fig. 4).

Therefore, we conclude that our rating curve is sufficiently robust to estimate discharge. Four uncertainty estimates were calculated (see Appendix A for more details): 1) uncertainty for the 46 individual discharge measurements, 2) uncertainty 
https://doi.org/10.5194/tc-2020-314

Preprint. Discussion started: 27 November 2020

(c) Author(s) 2020. CC BY 4.0 License.

(c) (i)

145 due to the rating curve, 3) uncertainty of daily mean discharge, and 4) uncertainty due to the stream bed incision into the ice over the melting season. While the uncertainty due to measurement errors $\left(\mathrm{U}_{\mathrm{me}}\right)$ was estimated as $10.8 \%$, uncertainty due to the rating curve $\left(\mathrm{U}_{\mathrm{RC}}\right)$ was estimated at $17 \%$. The measurement uncertainties were encompassed in the envelope of uncertainty due to the rating curve $\left(\mathrm{Q} \pm \mathrm{U}_{\mathrm{RC}}\right)$ (Fig. 4). The averaging of hourly discharge to daily mean discharge generated an uncertainty of $25 \%\left(\mathrm{X}_{\mathrm{dm}}\right)$. Uncertainty due to the stream bed incision was estimated using the cross-sectional profiles of the stream bed

150 (Fig. 3).

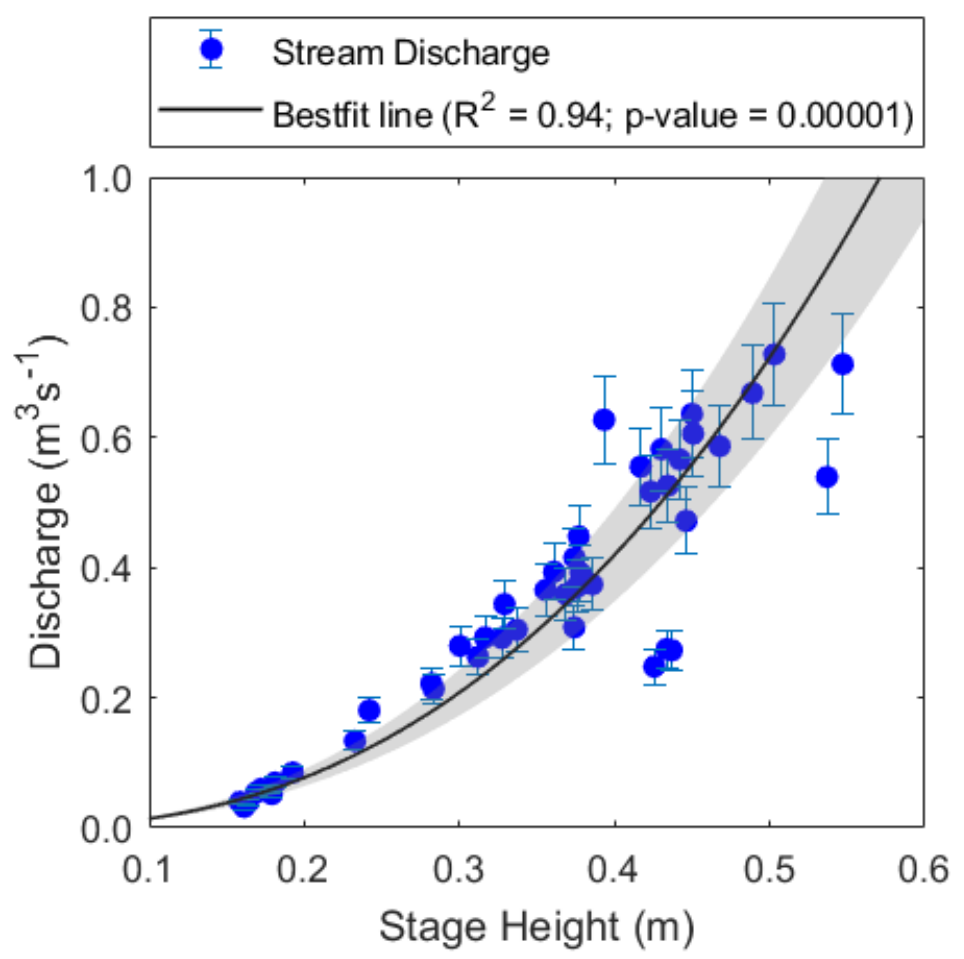

Figure 4: Rating curve (black line) determined from the best fit of power law (Eq. 1) to observations of stage and discharge (blue dots). Error bars show measurement error uncertainty $\left(U_{m e}\right)$. Rating curve uncertainty $\left(U_{R C}\right)$ is shown in the grey shaded area $(s e e$ Appendix A for uncertainty calculations).

Reconstructing hydrographs for supraglacial streams with high seasonal and diurnal variations with a rating curve is typically unreliable (Smith et al., 2017; Pitcher et al., 2019). In terrestrial rivers, shifts in the rating curve are a reflection of either a datum adjustment or changes in channel cross-section. Unlike terrestrial rivers, the bed under supraglacial streams is constantly melting and incising into the ice resulting in an ever-changing cross-sectional profile. To examine if our rating curve is robust despite channel cross-sectional profiles changes, we compared depth profiles collected while velocity was measured (Fig. 3). By separating profiles collected over high flows through the season from profiles collected over the 26-hr period of hourly measurements and assuming small incision over the 26-hour-period, depth measurement errors can be isolated from incision errors. While profiles collected over the season show a $3.7 \mathrm{~cm}$ standard deviation (Fig 3a), hourly 
profiles collected over the $26-\mathrm{hr}$ period show a $1.9 \mathrm{~cm}$ standard deviation (Fig 3b). The uncertainty in stream discharge (here we use the $95 \%$ confidence interval) due to non-uniform stream bed incision and depth measurement errors, $\mathrm{U}_{\text {in }}$ is $10.9 \%$ (of the average stream depth), and the depth measurement alone is $5.9 \%$. Despite these errors, the channel geometry incises uniformly through the season with all the cross-sections lying inside the uncertainty levels (Fig. 3a).

\subsection{Calculation of hydraulic geometry parameters}

Hydraulic geometry parameters were calculated to examine the relative importance of width, velocity, and depth in controlling discharge, and to compare with other studies reporting hydraulic geometry data for supraglacial streams. Hydraulic geometry is a set of equations that describes the relationship between discharge and stream channel geometry, namely, width, depth, and velocity (Leopold and Maddock, 1953):

$$
\begin{aligned}
& w=a Q^{b} \\
& d=c Q^{f} \\
& v=k Q^{m}
\end{aligned}
$$

175 where, $\mathrm{w}, \mathrm{d}$, and $\mathrm{v}$ are stream width, depth, and velocity of the cross-section, respectively. The exponents $\mathrm{b}$, $\mathrm{f}$, and $\mathrm{m}$ represent the slopes of the power laws. The magnitude of the exponents represents the rates of change of each variable with respect to the independent variable, discharge. The coefficients a, c, and k represent the y-axis intercepts. The law of conservation of mass implies that the product of coefficients a, c, and $\mathrm{k}$ should equal unity. Likewise, the sum of the exponents $\mathrm{b}$, $\mathrm{f}$, and $\mathrm{m}$ should also equal unity (Leopold and Maddock, 1953).

\subsection{Automatic weather station observations in the 660 catchment}

To identify the timing of daily maximum melt during clear sky days, a shortwave pyranometer (HOBO S-LIBM003) was mounted at $2 \mathrm{~m}$ height on an automated weather station (AWS) 20-25 $\mathrm{m}$ from the gauging station. Other meteorological data were measured at this station and are a part of the dataset accompanying this paper. However, better data continuity and accuracy is provided by the nearby AWS, KAN_L, located $\sim 7 \mathrm{~km}$ southeast of our study area. Therefore, meteorological data from KAN_L were used in our analysis. The KAN_L AWS is maintained by the Geological Survey of Denmark and Greenland (GEUS) (van As et al., 2011).

\subsection{Surface energy balance model}

To examine surface energy drivers of supraglacial discharge, energy balance components were obtained from a surface energy balance model (described in van As, 2011). This model uses forcing data from in-situ meteorological and radiative observations from KAN_L to calculate the surface energy balance components net shortwave radiation, net 
https://doi.org/10.5194/tc-2020-314

Preprint. Discussion started: 27 November 2020

(c) Author(s) 2020. CC BY 4.0 License.

(c) (i)

longwave radiation, sensible heat flux, latent heat flux, sub-surface conductive heat flux, and heat flux from rain. While incoming shortwave and longwave radiation are gathered from the AWS, turbulent heat fluxes are calculated from nearsurface gradients of meteorological variables, air temperature, humidity, and wind speed using Monin-Obukhov similarity theory.

\subsection{Catchment delineation}

The catchment boundary and supraglacial stream network were manually digitized using two sources. Firstly, we used WorldView-1 (WV1) panchromatic imagery (spatial resolution of $1 \mathrm{~m}$ ) acquired on 16 August 2016 to manually digitize the stream network. We also collected 20,000 handheld GPS points of the catchment boundary in the field, by walking along the catchment divide separating the stream network from adjacent catchments. We did not observe a change in catchment size during the study period. We estimate the catchment area to be accurate within 5\% given that it was manually identified in the field. However, the precise delineation of the catchment is not relevant to the outcome of the study.

\section{Results}

Our catchment has a dendritic drainage pattern (Strahler order $=4$ ), and is internally drained, meaning that all surface meltwater is routed through streams, tributaries, and ponds to a terminal moulin (Fig. 1). Repeated visits to the study site between 2013-2019, suggest that this network, with streams $\sim 0.1-15 \mathrm{~m}$ widths and $\sim 0.1-2 \mathrm{~m}$ depths, is an annually recurrent feature of the local hydrological system. A new tributary joining the network was observed in 2017 but does not affect the present study.

\subsection{Hourly and daily variations in supraglacial discharge}

Stream discharge between 13 June and 13 August varies strongly both diurnally and seasonally (Fig. 5a). Hourly discharge fell as low as $0 \mathrm{~m}^{3} \mathrm{~s}^{-1}$ at night and daily peaks exceeded $0.3 \mathrm{~m}^{3} \mathrm{~s}^{-1}$ on most days. Three distinct melt episodes with larger discharges were recorded on $13 \mathrm{June}\left(0.81 \mathrm{~m}^{3} \mathrm{~s}^{-1}\right)$, $19 \mathrm{June}\left(0.94 \mathrm{~m}^{3} \mathrm{~s}^{-1}\right)$, and $16 \mathrm{July}\left(0.93 \mathrm{~m}^{3} \mathrm{~s}^{-1}\right)$. During these times peak flows were almost double the long-term average of daily maximum discharge $\left(0.5 \mathrm{~m}^{3} \mathrm{~s}^{-1}\right)$ and occurred around 15:00 local time.

Daily maximum discharge varies from $0.05-0.94 \mathrm{~m}^{3} \mathrm{~s}^{-1}$ through the season, with the highest values around the three

215 melt episodes (Fig. 5b). Daily minimum discharge has much less seasonal variability than daily maximum discharge but exhibits two occurrences with anomalously larger flow on 23 June and 19 July (Fig. 5b). During the melt episodes, these positive anomalies in daily minimum discharge follow a steep decrease in daily maximum discharge, meaning, the anomalously large low flows at night follow a dip in day-time streamflow. Compared to the first and second episodes, daily minimum discharge behaves differently after the third episode. After the second episode, and before the third episode begins, night-time low-flow discharge occasionally falls as low as $0 \mathrm{~m}^{3} \mathrm{~s}^{-1}$ but rises to $0.04 \mathrm{~m}^{3} \mathrm{~s}^{-1}$ after the third episode. Finally, the diurnal amplitude (daily maximum minus daily minimum) tracks daily maximum discharge except for the second and third 
https://doi.org/10.5194/tc-2020-314

Preprint. Discussion started: 27 November 2020

(c) Author(s) 2020. CC BY 4.0 License.

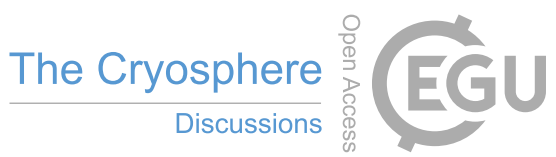

melt episodes with large daily minimum discharge (Fig. 5c). After the third melt episode, there is a steady decline in diurnal amplitude from $0.64-0.33 \mathrm{~m}^{3} \mathrm{~s}^{-1}$ (21 July-13 August).

(a)
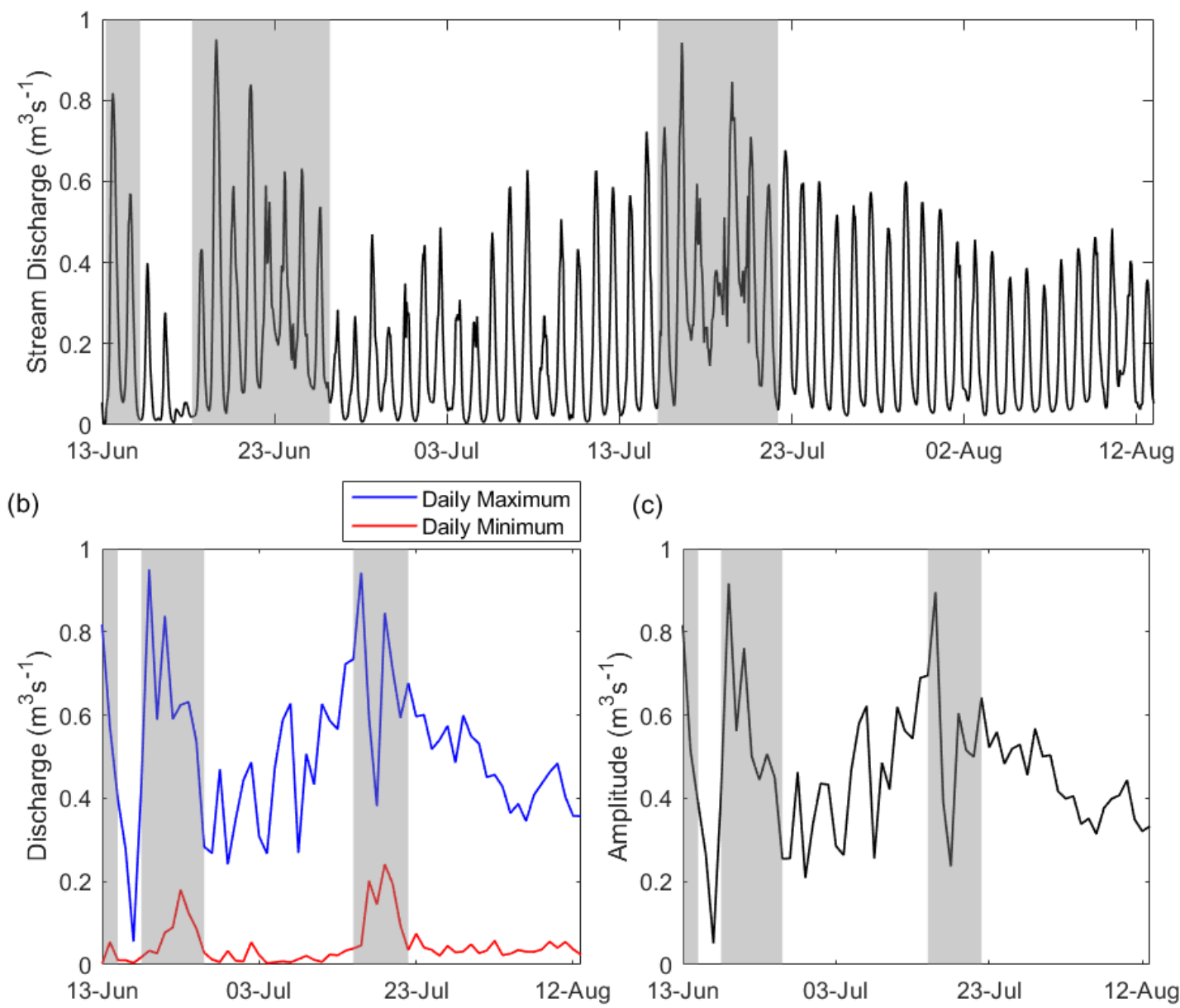

(c)

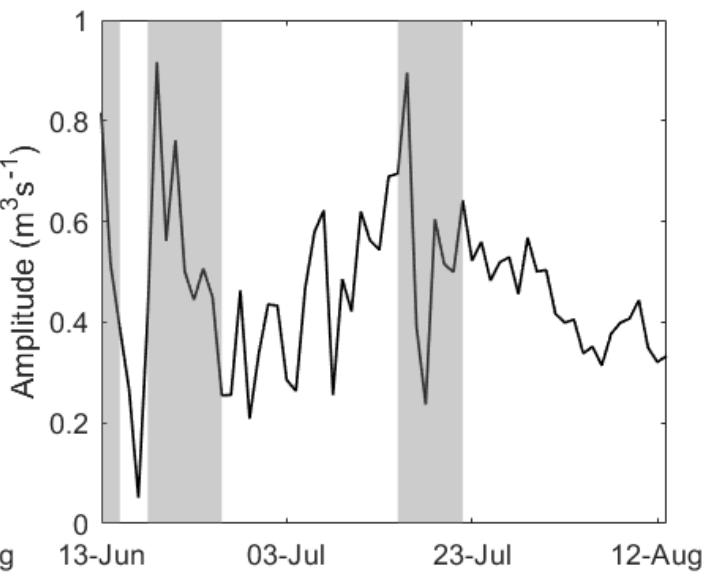

225 Figure 5: (a) Hourly stream discharge generated using the rating curve (Fig. 4) over 62 days of the melting season. (b) Daily maximum (in blue) and daily minimum (in red) discharge, calculated from the hourly discharge. (c) Amplitude (daily maximum minus daily minimum) of the stream discharge. Three large melt episodes are shown in grey shaded regions.

The daily mean discharge varies from $0-0.51 \mathrm{~m}^{3} \mathrm{~s}^{-1}$ over the 62 days (Fig. 6a) and co-varies seasonally with daily maximum discharge except for the timing of the peak daily mean discharge (Fig. 5b). The daily mean discharge peaks on 19 July, three days after the second-largest melt episode in hourly discharge. In contrast, the second largest peak in daily mean flow occurs on 20 June, which is the same day as the largest episode in hourly discharge. In both cases, hourly maximum discharge is accompanied by several days of very high daily minimum flows (Fig. 5b), which explains the discrepancy between the timing of the daily mean and daily maximum episodes. 
(a)

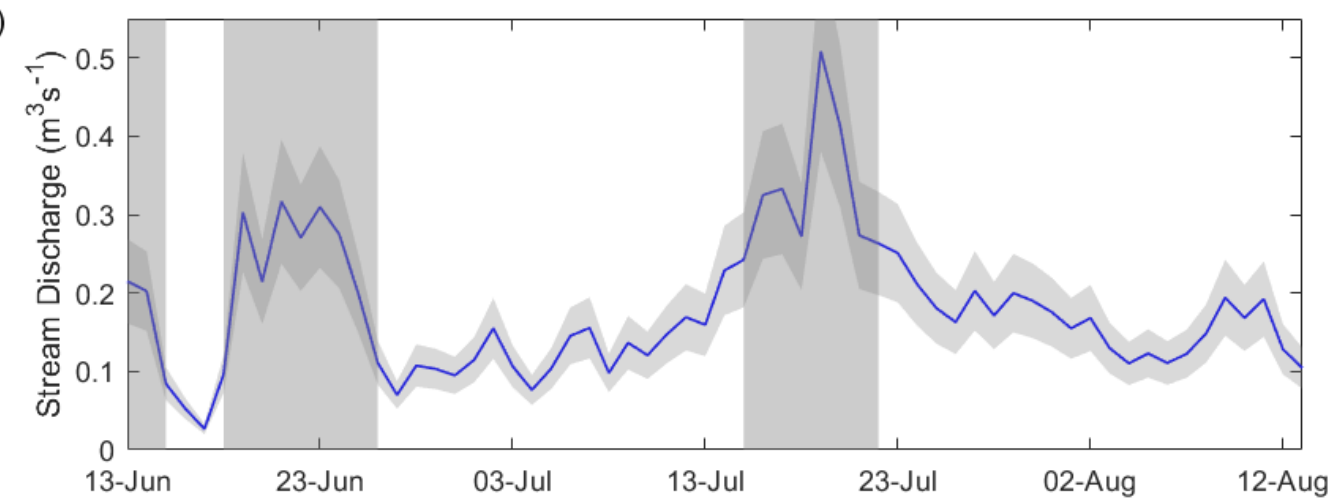

(b)

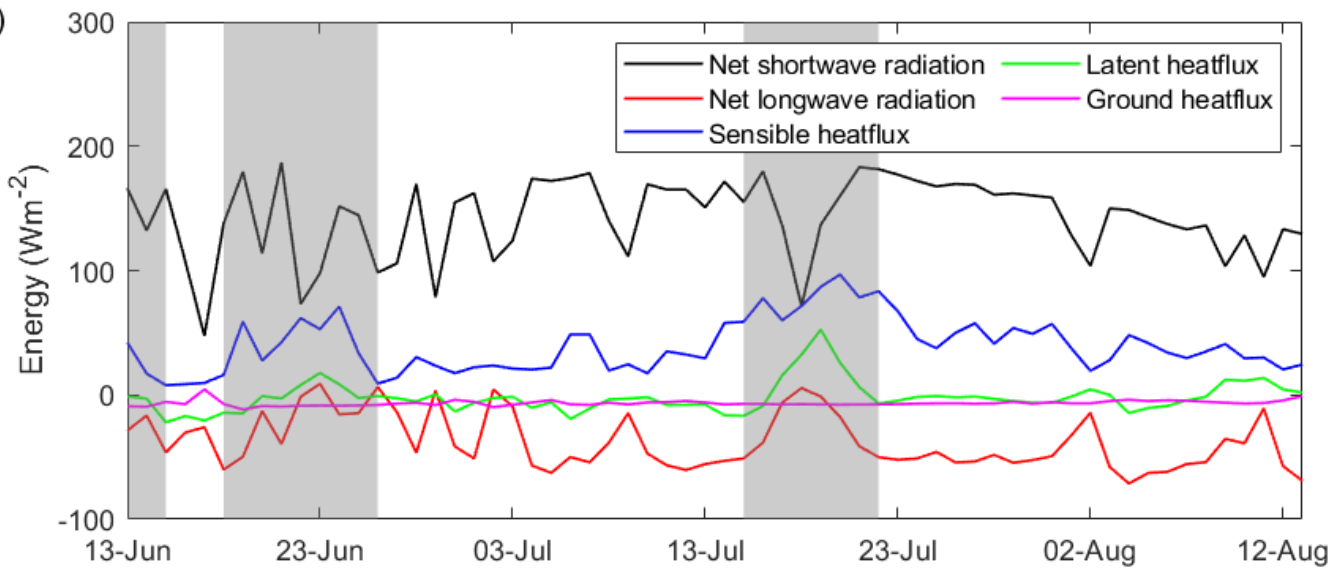

235 Figure 6:(a) Daily discharge measured by averaging the hourly discharge from Fig. 5a. Uncertainty of daily mean discharge generated by averaging hourly discharge, $\mathbf{X}_{\mathrm{dm}}$, is shown in the grey shaded area (see Appendix A for uncertainty calculations), (b) surface energy components, net shortwave radiation (black), net longwave radiation (red), sensible heat flux (blue), latent heat flux (green), and ground heat flux (magenta). Large melt episodes are shown in grey shaded regions.

\subsection{Surface energy balance}

Throughout the season, net shortwave radiation exceeds all other surface energy fluxes and thus is the primary driver of stream discharge (Fig. 6b). However, the second and third melt episodes coincide with peak longwave radiation $\left(65 \mathrm{Wm}^{-2}\right.$ increase) and turbulent heat fluxes (40-80 $\mathrm{Wm}^{-2}$ increase) along with a drop in shortwave radiation (110-120 $\mathrm{Wm}^{-2}$ decrease) (Fig. 6). Thus, during high-melt episodes, longwave radiation and turbulent heat fluxes become more pronounced drivers of streamflow. Among all energy fluxes, sensible heat flux correlates most with daily mean discharge $(\mathrm{R}=0.88, \mathrm{p}$-value $=$ 0.00001). During the third melt episode, the hourly peak discharge coincides with a peak in shortwave radiation on 16 July (Fig. 7a). However, the peak daily mean discharge occurs three days later on 19 July 2016 due to high net longwave radiation and turbulent heat fluxes from 16-20 July (Fig. 6). This high net longwave radiation was caused by overcast conditions (Fig. 7b) and resulted in a high low flow at night (Fig. 7a). The consistently large low-flow persisted from 17 to 20 July (Fig. 7a) and resulted in the seasonal peak discharge on 19 July $\left(0.51 \mathrm{~m}^{3} \mathrm{~s}^{-1}\right)$ (Fig. 6a). This can also be seen in the hourly variation of 
https://doi.org/10.5194/tc-2020-314

Preprint. Discussion started: 27 November 2020

(c) Author(s) 2020. CC BY 4.0 License.

surface energy balance components and stream discharge (Fig. 7a). Between 17-20 July, night-time streamflow is much higher than before and after (Fig. 7a), and coincides with increased net longwave radiation. While a dip in shortwave radiation on 18 July decreases the high flow during the day, the low flow during the night increases due to a spike in net longwave radiation (Fig. 7a).

(a)

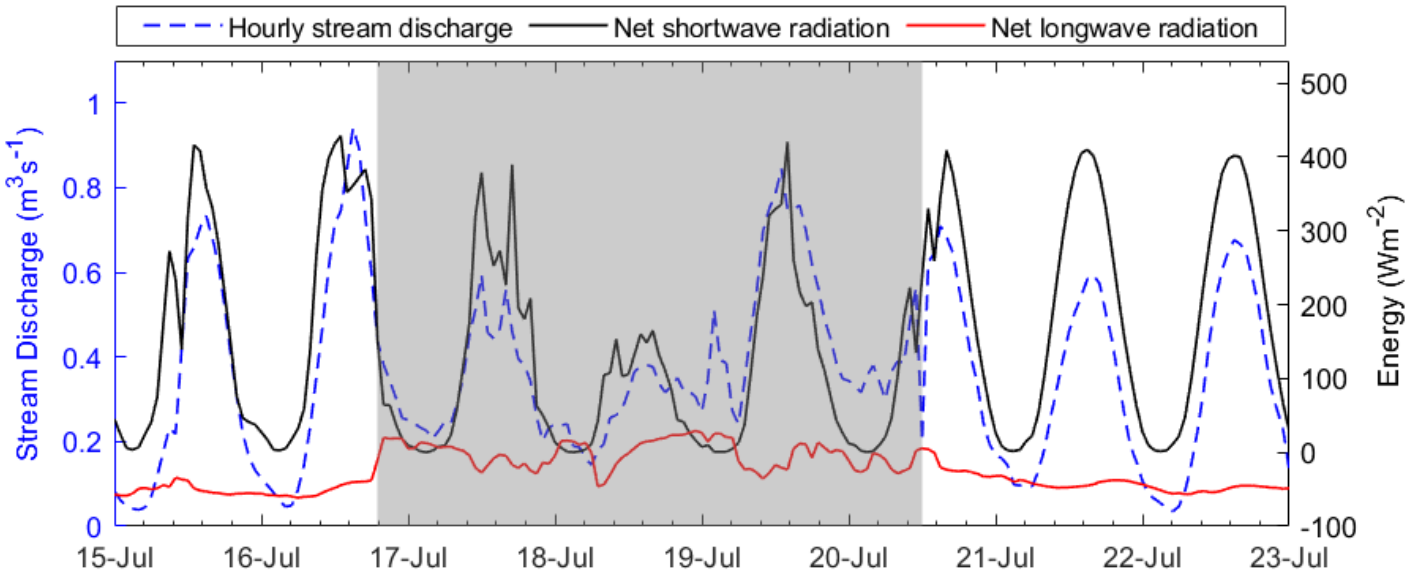

(b)

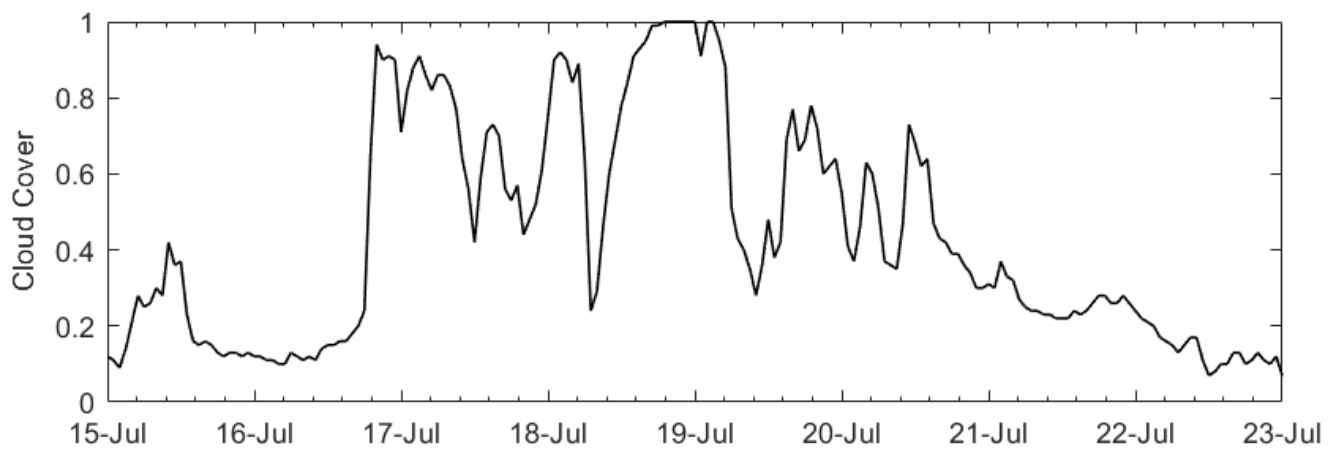

255 Figure 7: (a) Diurnal fluctuations in stream discharge on the left y-axis (blue dotted line) and surface energy balance components on the right $y$-axis, net shortwave radiation in black, and net longwave radiation in red from 15-22 July. The large daily minimum period (a subset of the third melt episode) is shown in the grey shaded region. (b) Cloud cover at the KAN L station from 15-22 July.

To further examine the difference in energy balance components' contribution to high versus low stream discharge, we aggregated components for the second and third melt episodes, and compared to all-season data (Fig. 8). The shortwave radiation proportion of melt energy fell from $78 \%$ to $50 \%$ (normalized) during the melt episodes. Simultaneously, the contribution of longwave radiation and turbulent heat fluxes increased during those days. The longwave radiation's proportion of melt energy increased from a seasonal average of -0.32 to -0.085 during the peak flow days (increased by $16.5 \%$ ), while sensible and latent heat fluxes' proportion of melt energy increased by $0.06(4 \%)$ and 0.11 (7\%) during the melt episodes, respectively. 


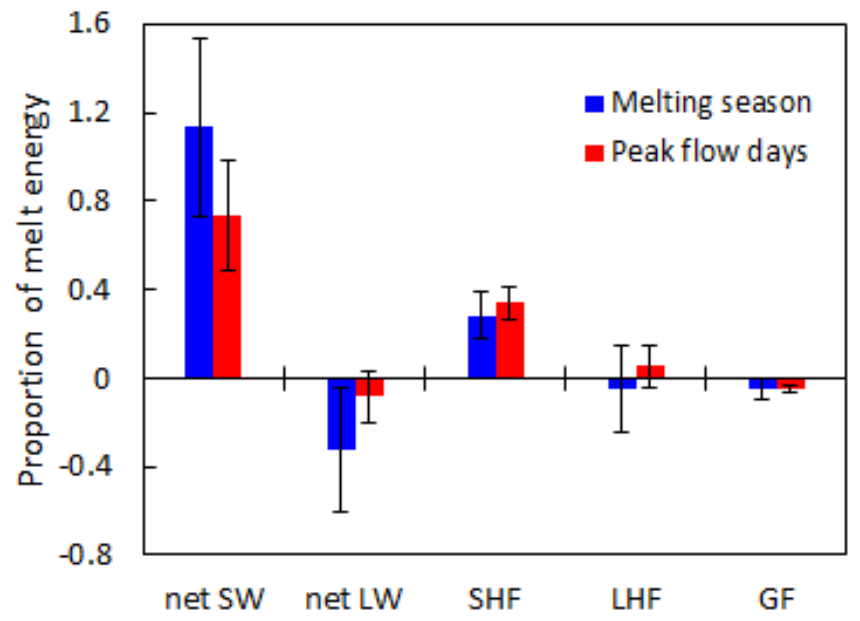

Figure 8: Proportion of melt energy (ratio of each component to total melt energy) for the whole melting season in blue and for the days during the melt episodes only in red. Here, peak flow days include days from the second melt episode (19-23 June) and the third melt episode (16-20 July). Error bars represent standard deviation of each sample.

\subsection{Timing of peak daily discharge}

To examine if the transport of meltwater from its production on the ice sheet surface to the discharge observation site varies over the season, we calculated time to daily maximum discharge, following 'time-to-peak' methodology in traditional terrestrial hydrology (Chow, 1964). As the season progresses, the time to daily maximum discharge will reflect changes in network storage and transport efficiency. In contrast, during clear-sky days, when solar radiation drives melt, the timing of daily maximum surface meltwater creation is not expected to change over the season and be proportional to solar noon. While the incoming solar radiation peaks at solar noon around 13:15 local time, the timing of the daily maximum discharge varies from 16:00 in late June to 14:00 in late July (Fig. 9a). The time lag between the solar and discharge peaks changes from 3 hours to 1 hour from 30 June to 31 July and has a statistically significant negative trend $\left(R^{2}=0.793\right.$, $p$-value $\left.=0.00011\right)$. After 31 July, the time lag abruptly shifts back to initial season conditions and stabilizes at 3 hours in early August. This shift in the lag coincides with the sudden decrease in daily mean temperatures from $4.3{ }^{\circ} \mathrm{C}$ on 31 July to $2.5^{\circ} \mathrm{C}$ on 3 August (Fig. 9b).

280 Though the daily mean temperature started to decrease after the third melt episode on 19 July, the sudden drop in early August coincides with the shift in time of daily maximum discharge due to a drop in night-time temperatures close to $1{ }^{\circ} \mathrm{C}$ (Fig. $9 \mathrm{~b}$ ). These air temperature measurements were collected at $2 \mathrm{~m}$ above the surface and therefore the skin temperatures are expected to be below freezing. 


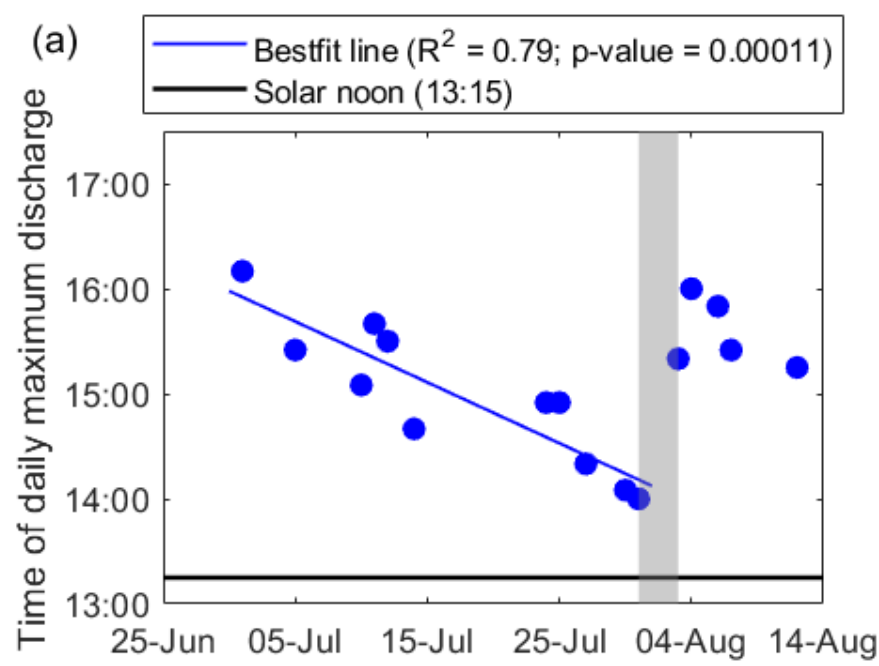

(b)
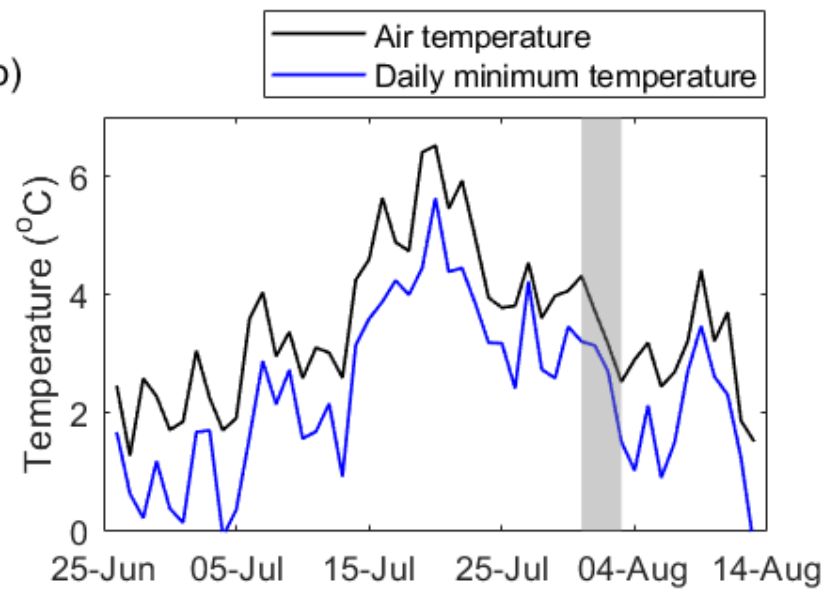

Figure 9: (a) Time to daily maximum discharge for clear sky days. Clear sky days were identified as days with incoming solar radiation (from KAN_L AWS data) with a smooth diurnal cycle and lacking short-term, hourly, fluctuations from varying cloud cover. (b) Daily mean air temperature from KAN_L AWS. The period, where change in time of daily maximum discharge coincides with a sudden drop in temperature from 1-3 Aug, is shown in the grey shaded region.

\subsection{Hydraulic Geometry}

Hydraulic geometry parameters are determined by generating a power law between stream discharge, and width $\left(\mathrm{R}^{2}\right.$ $=0.87, \mathrm{p}$-value $=0.00001)$, depth $\left(\mathrm{R}^{2}=0.94, \mathrm{p}\right.$-value $\left.=0.00001\right)$ and velocity $\left(\mathrm{R}^{2}=0.88, \mathrm{p}\right.$-value $\left.=0.00001\right)($ Eq. $2-4$ respectively). For the 660 catchment, the exponents b, f, and $\mathrm{m}$ are $0.194,0.387$ and 0.373 respectively, and coefficients a, c, and $\mathrm{k}$ are $3.44,0.541$, and 0.632 respectively. While the sum of the exponents of these power laws, representing sensitivity of discharge to the individual variable, equals 1, the product of the coefficients must also equal 1 (Leopold and Maddock, 1953). In our study the sum of exponents equals 0.95 and the product of coefficients equals 1.17. 
https://doi.org/10.5194/tc-2020-314

Preprint. Discussion started: 27 November 2020

(c) Author(s) 2020. CC BY 4.0 License.

(c) (P)

\section{Discussion}

Here, we present a 62-day time-series of supraglacial stream discharge (13 June-13 August 2016). We find strong diurnal variability in stream discharge, similar to previous in situ studies of supraglacial streamflow (Holmes, 1955; Knighton, 1981; Marston, 1983; Mernild et al., 2006; McGrath et al., 2011; Chandler et al., 2013; Smith et al., 2017), despite different locations. Diurnal variability ranges from $0.002-0.95 \mathrm{~m}^{3} \mathrm{~s}^{-1}$ with daily maximum discharge occurring between 14:00-16:00 local time throughout the study period. Both diurnal variability and time of maximum discharge are comparable to McGrath et al. (2011), who documented diurnal variability of $0.017-0.54 \mathrm{~m}^{3} \mathrm{~s}^{-1}$ with a daily maximum discharge at 16:45 local time over a catchment (in Sermeq Avannarleq ablation zone in central-west Greenland) of area $1.14 \pm 0.06 \mathrm{~km}^{2}$ from $3-$ 17 August 2009 (Table 1). Marston (1983) also finds a similar range of discharge varying between $0-0.23 \mathrm{~m}^{3} \mathrm{~s}^{-1}$ with a daily

305 maximum discharge occurring between 14:00-16:00 local time in Juneau Icefield around late July. Mernild et al. (2006) and Chandler et al. (2013) show a larger catchment, over southeast and southwest Greenland respectively, with a diurnal variability up to 10 times larger than at the 660 catchment and a daily maximum discharge occurring between 14:00-18:00. The oldest study we are aware of, Holmes (1955), reports supraglacial stream discharge of $0.14-5 \mathrm{~m}^{3} \mathrm{~s}^{-1}$ (about five times larger than at the 660 catchment) at a catchment of $25-50 \mathrm{~km}^{2}$ (much larger than the 660 catchment) with a daily maximum discharge occurring between 16:00-20:00 local time in southwest Greenland. In a study by Smith et al. (2017) in a much larger $\left(63 \mathrm{~km}^{2}\right)$ supraglacial catchment, daily maximum discharge occurred between 18:00-20:00 local time, and discharge varied between 5-26 $\mathrm{m}^{3} \mathrm{~s}^{-1}$ (Table 1). In all studies providing time-series of stream discharge (Marston, 1983; Mernild et al., 2006; McGrath et al., 2011; Chandler et al., 2013; Smith et al., 2017), the lag between solar noon and daily maximum discharge is larger for the larger magnitude of stream discharge, due to runoff generation from a larger catchment area, thus increasing the distance of surface routing and a later peak of daily discharge at the catchment outlet (Smith et al., 2017).

In addition to the diurnal variability, supraglacial stream discharge exhibits strong seasonal variability at the 660 catchment. We observed three melt episodes of high discharge, one peaking on 13 June (350\% of mean discharge), a second on 19 June (400\% of mean discharge), and a third on 16 July (400\% of mean discharge) (Fig. 5a). The timing of these episodes corresponds with periods of anomalous high river discharge observed $\sim 35 \mathrm{~km}$ downstream in the Watson River, Kangerlussuaq (van As et al., 2018). The 660 catchment is a very small subcatchment of the Watson River catchment (12000 $\left.\mathrm{km}^{2}\right)$.

Over the 62-day study period, while net shortwave radiation provides the majority of melt energy and is the primary driver of streamflow, net longwave radiation and turbulent heat fluxes (sensible and latent) become more dominant melt drivers during the three melt episodes (Fig. 8). These findings agree with Greenland-wide studies identifying a link between longwave radiation and enhanced surface melting (Van Tricht et al., 2016; Gallagher et al., 2020) while disagreeing with studies suggesting that overcast conditions and lower solar radiation reduce surface melt in the ablation zone (Hofer et al., 2017; Izeboud et al., 2020). Furthermore, we find that daily average sensible heat flux has the highest correlation with stream discharge $\left(\mathrm{R}^{2}=0.83\right.$, $\mathrm{p}$-value $\left.=0.00001\right)$ of all energy balance components (e.g. net shortwave radiation, $\mathrm{R}^{2}=0.23$, $\mathrm{p}$ - 
https://doi.org/10.5194/tc-2020-314

Preprint. Discussion started: 27 November 2020

(c) Author(s) 2020. CC BY 4.0 License.

value $=0.035$ ). Correlating energy components with stream discharge is justified here due to the quick routing in this catchment (1-3 hours). This contribution of sensible heat flux is consistent with Fausto et al. (2016), who show that peak melting occurs at times with anomalously large turbulent energy fluxes.

Table 1: Table of measured supraglacial streamflow, width and catchment size from this and previous studies. "Width" denotes stream width and "Lag" is the time of peak discharge after solar noon.

\begin{tabular}{|c|c|c|c|c|c|c|}
\hline Source & Location & Time & $\begin{array}{l}\text { Discharge } \\
\left(\mathrm{m}^{3} \mathrm{~s}^{-1}\right)\end{array}$ & Width (m) & $\begin{array}{l}\text { Catchment } \\
\text { Area }\left(\mathrm{km}^{2}\right)\end{array}$ & $\begin{array}{l}\text { Lag } \\
\text { (hours) }\end{array}$ \\
\hline $\begin{array}{l}\text { Holmes et } \\
\text { al. (1955) }\end{array}$ & $\begin{array}{l}\text { Alpha River, Project } \\
\text { Mint Julep, southwest } \\
\text { Greenland }\end{array}$ & $\begin{array}{c}21 \text { July }-15 \\
\text { August, } 1953\end{array}$ & $0.14-5.11$ & 9 & $25-50$ & $3-7$ \\
\hline $\begin{array}{l}\text { Knighton } \\
\text { (1981) }\end{array}$ & $\begin{array}{l}\text { Austre Okstindbreen, } \\
\text { Norway }\end{array}$ & NA & $0.005-0.02$ & $0.2-0.5$ & NA & NA \\
\hline $\begin{array}{l}\text { Marston } \\
\text { (1983) }\end{array}$ & Juneau Icefield & $\begin{array}{c}28 \text { July }-2 \\
\text { August, } 1983\end{array}$ & $0-0.24$ & $0.7-1.6$ & NA & $2-3$ \\
\hline $\begin{array}{l}\text { Mernild et } \\
\text { al. (2006) }\end{array}$ & $\begin{array}{l}\text { Mittivakkat Glacier, } \\
\text { southeast Greenland }\end{array}$ & $\begin{array}{c}16-19 \text { August } \\
2004, \\
15-18 \\
\text { June } 2005 \\
\end{array}$ & $5-10$ & NA & 18.4 & $\begin{array}{c}3-4 \\
\text { (August) } \\
5-7 \\
\text { (May) }\end{array}$ \\
\hline $\begin{array}{l}\text { McGrath et } \\
\text { al. (2011) }\end{array}$ & West Greenland & $\begin{array}{c}3-17 \text { August, } \\
2009\end{array}$ & $0.017-0.54$ & $0-2.5$ & $1.14 \pm 0.06$ & $3-4$ \\
\hline $\begin{array}{l}\text { Chandler et } \\
\text { al. (2013) }\end{array}$ & $\begin{array}{l}\text { Moulin L41- } \\
\text { internally drained } \\
\text { catchment (part of } \\
\text { Leverett catchment), } \\
\text { southwest Greenland }\end{array}$ & $\begin{array}{c}29 \text { June }-7 \text { July } \\
17-20 \text { August, } \\
2011\end{array}$ & $0-8$ & NA & NA & $\begin{array}{c}3-6 \\
\text { (July) } \\
6-8 \\
\text { (August) }\end{array}$ \\
\hline $\begin{array}{l}\text { Gleason et } \\
\text { al. (2016), } \\
\text { (\& Smith et } \\
\text { al., 2015)* }\end{array}$ & Southwest Greenland & $\begin{array}{l}\text { July - August, } \\
2012\end{array}$ & $\begin{array}{c}0.006-0.402 \\
\quad(\text { small } \\
\text { streams }) \\
4.58-23.12 \\
\text { (large streams) }\end{array}$ & $\begin{array}{c}0.2-3.84 \\
(\text { small } \\
\text { streams) } \\
7.19-20.62 \\
\text { (large } \\
\text { streams) } \\
\end{array}$ & NA & NA \\
\hline $\begin{array}{l}\text { Smith et al. } \\
(2017)\end{array}$ & Southwest Greenland & $\begin{array}{c}20-23 \text { July, } \\
2015\end{array}$ & $4.61-26.73$ & $2.4 \pm 1.5$ & 63.1 & $4-6$ \\
\hline $\begin{array}{l}660 \\
\text { Catchment }\end{array}$ & Southwest Greenland & $\begin{array}{c}13 \text { June }-13 \\
\text { August, } 2016\end{array}$ & $0.1-0.95$ & $1.6-3.2$ & 0.6 & $1-3$ \\
\hline
\end{tabular}

We find that the time of maximum diurnal discharge varies from 16:00 in late June to 14:00 in late July (Fig. 9a), which translates to a lag between maximum diurnal melt and maximum diurnal discharge from 1-3 hours. This lag is 
https://doi.org/10.5194/tc-2020-314

Preprint. Discussion started: 27 November 2020

(c) Author(s) 2020. CC BY 4.0 License.

(c) (i)

consistent with the previous studies, where it varies from 3-9.5 hours (Holmes, 1955; Mernild et al., 2006; McGrath et al., 2011; Chandler et al., 2013; Smith et al., 2017). The difference in lag is most likely due to the difference in the size of catchment. While large catchments in Holmes (1955), Mernild et al. (2006), Chandler et al. (2013) and Smith et al. (2017)

340 show lags between 3-9.5 hours, smaller catchments in Marston (1983) and McGrath et al. (2011) show lags between 2-4 hours (Table 1). For the 660 catchment, the lag decreases through the season from 3 hours in late June to 1 hour in late July, consistent with the change in lag through the melting season shown by Mernild et al. (2006) from 5-7 hours in May to 3-4 hours in August. Furthermore, at the 660 catchment, in early August, the lag abruptly increases to the initial season conditions and stabilizes at 3 hours, coinciding with a sudden drop in air temperature from $4.3^{\circ} \mathrm{C}$ to $2.5^{\circ} \mathrm{C}$ from 31 July to 3

345 August (Fig. 9b). With the night-time air temperatures close to $1{ }^{\circ} \mathrm{C}$, the skin temperatures could be below freezing affecting the efficiency of the stream network, thereby increasing the temporary storage of melt generated in the weathering crust, and delay the transport of melt to the moulin. This phenomenon of a shift in the timing of daily maximum discharge agrees with the model study by Yang et al. (2018), who shows that a poorly developed stream network has delayed timing of peak and up to half the diurnal variation in stream discharge relative to a well-developed and an efficient network.

Our work confirms the findings by Gleason et al. (2016) that hydraulic geometry parameters cannot be generalized for supraglacial rivers in Greenland, despite having a common ice substrate. Comparing our data with parameters from previous studies (Knighton, 1981; Marston, 1983; Gleason et al., 2016) in a ternary diagram reveals three clusters (Fig. 10). These three clusters can be grouped based on their b-values (width power-law exponent). The first cluster has high $b$-values $(b>=0.35)$ and includes the downstream station of Gleason et al. (2016), which are smaller streams with discharge varying between 0.006 to $0.402 \mathrm{~m}^{3} \mathrm{~s}^{-1}$. The second cluster has low b-values $(b<=0.05)$ and includes at-a-station data from Gleason et al. (2016), which are larger streams with discharge varying between 4.58 to $23.12 \mathrm{~m}^{3} \mathrm{~s}^{-1}$. Finally, the third cluster has moderate b-values $(0.05<b<0.35)$, and includes this study, and Knighton (1981) and Marston (1983). Though the discharge from Knighton (1981) is two orders smaller than ours, Marston (1983) has similar discharge values (Table 1). The streams with discharge of same order of magnitude i.e., varying between 0-1 $\mathrm{m}^{3} \mathrm{~s}^{-1}$, from Knighton (1981), Marston (1983), and the current study show moderate sensitivity to stream width (moderate values of $b$ ) and streams with higher magnitude of discharge show very small sensitivity to stream width (smaller values of b). However, small streams from Gleason et al. (2016) do not concur with this generalization and show a high sensitivity to stream width (large b-values). 


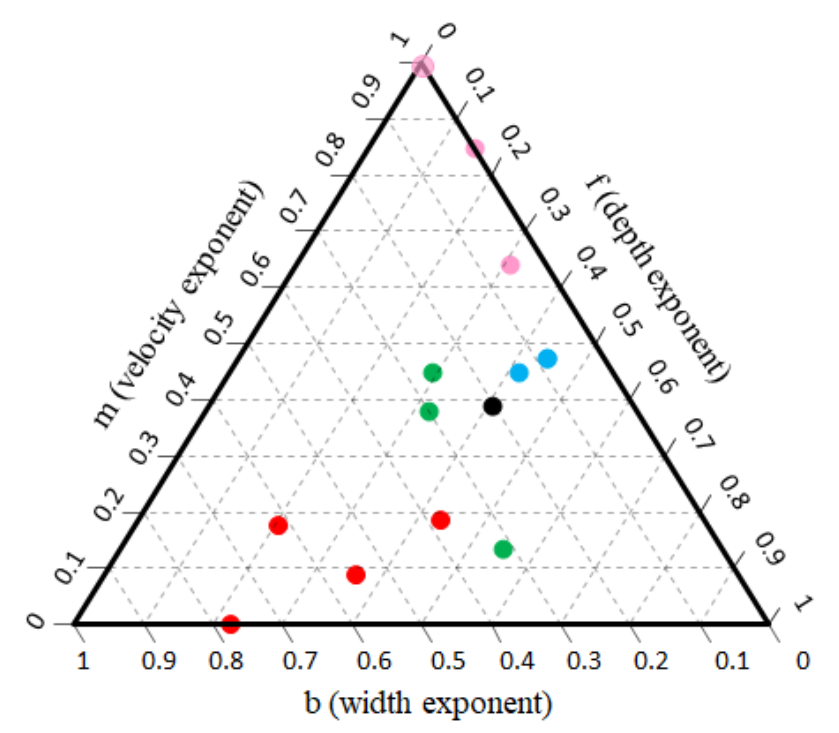

\begin{tabular}{|llll|}
\hline Knighton (1981) & Gleason et al. (2016) - small streams \\
Marston (1983) & Gur Study & Gleason et al. (2016) - large streams \\
\hline
\end{tabular}

Figure 10: Ternary diagram comparing $\mathrm{m}$, f, and b parameters from this study (in black) with previous work by Knighton (1981) in blue, Marston (1983) in green, and Gleason et al. (2016) large streams in pink and small streams in red. Where $\mathrm{m}+\mathrm{f}+\mathrm{b}$ exceeded unity, parameters were adjusted to unity.

Our analysis of a season-long record of streamflow and its drivers has several implications for large-scale Greenland ice sheet hydrology. First, we confirm Gleason et al. (2016)'s work by finding that hydraulic geometry parameters vary across ice sheet catchments. Thus, using generalized parameter space to estimate supraglacial streamflow from ungauged catchments may not be valid. Second, we find that longwave radiation and turbulent fluxes have an increased contribution (adding up to $50 \%$ of melt energy), in governing stream discharge during the melt episodes. Given that several regional climate models underestimate turbulent fluxes, they also will underestimate melt episodes (van den Broeke et al., 2011; and Fausto et al., 2016). Since the most accurate way to estimate surface runoff from the entire Greenland ice sheet is through regional climate/surface mass balance models (Fettweis et al., 2017; Mernild et al., 2018; Noel et al., 2018), underestimating turbulent heat fluxes also underestimates runoff. Third, with the lack of lengthy records of supraglacial stream discharge over the Greenland ice sheet, the 62-day long time series could expand climate/surface mass balance models validation capability to a great extent. Currently, the only study to validate model simulated runoff used field observations of streamflow covering just 3 days (Smith et al. 2017). Lastly, the accurate timing and magnitude of peak discharge can help understand its influence on subglacial water pressure and ice velocities, although the impact of stream velocities are probably minor from this catchment since it is located very close to the ice sheet margin. 


\section{Conclusions}

We present one of the longest records of Greenland supraglacial stream discharge, spanning 62-days of the 2016 melting season for a $0.6 \mathrm{~km}^{2}$ catchment in southwest Greenland. These long-term observations could be used in validating regional climate models, currently the best tools to estimate surface runoff from the entire Greenland ice sheet. Concurring with the previous studies, we show that hydraulic geometry parameters cannot be generalized for supraglacial rivers in Greenland. The observed stream discharges vary both seasonally and diurnally. Our record includes three distinct episodes of large discharge, one from 13-14 June, the second one from 19-25 June, and the third one from 15-21 July. The daily maximum discharge and amplitude show similar seasonal and diurnal variation except during the second and third melt episodes when nighttime melting reduced the daily amplitude. During the third melt episode, the large daily discharge minimums, caused by high longwave radiation, drive the seasonal peak discharge on 19 July with continuous high flow in the day and night for 3-4 days (16-19 July). The stream discharge is primarily driven by net shortwave radiation through the melting season, except during the high melt episodes when net longwave radiation and turbulent heat fluxes show an increased contribution (16\% and 4-7\% respectively) to melt energy. The lag between the time of daily maximum discharge and time of daily maximum melt (assumed to be solar noon here) varies through the season from 3 hours in late June to 1 hour in late July and goes back to 3 hours in early August due to a sudden drop in air temperature. This change in lag could be due to the expansion and contraction of the stream network, caused by probable freezing skin temperatures at night, affecting network efficiency and therefore, change in routing time of the melt. Though this theory was explained by a model simulation from Yang et al. (2018), further work is required to reveal if the rapid shift in the timing of peak discharge, we notice at the 660 catchment, also takes place across Greenland supraglacial streams and analyze the influence of stream network development on timing and magnitude of peak discharge.

\section{Appendix A: Streamflow uncertainty}

The uncertainty of the 46 individual discharge observations due to seven different types of measurement errors in velocity and stage height was calculated following Herschy (2002) and WMO (2010), and assumes that segment discharges and standard uncertainties are approximately equal in each of the segments in the cross-section:

$U_{m e}(Q)=K \sqrt{u_{m}^{2}+u_{s}^{2}+\frac{1}{M}\left\{u_{b}^{2}+u_{d}^{2}+u_{p}^{2}+u_{c}^{2}+u_{e}^{2}\right\}}$

where $\mathrm{U}_{\mathrm{me}}$ is uncertainty due to measurement errors, $\mathrm{Q}$ is discharge, $\mathrm{K}$ is the so called coverage factor ( $\mathrm{K}=2$ gives the $95 \%$ confidence interval), $u_{m}$ is uncertainty in determination of mean velocity for number of verticals $(M)$, $u_{s}$ is uncertainty due to calibration errors, $u_{b}$ is uncertainty in width, $u_{d}$ is uncertainty in depth, $u_{p}$ is uncertainty in determination of mean velocity for 
uncertainty in determination of mean velocity for time of exposure. A summary of all nomenclature used in this study is found in Table A1.

Table A1: Nomenclature used in this paper

\begin{tabular}{|c|c|c|}
\hline Symbol & Unit & Description \\
\hline $\mathrm{H}$ & $\mathrm{m}$ & Stage height \\
\hline Q & $\mathrm{m}^{3} \mathrm{~s}^{-1}$ & Discharge \\
\hline $\mathrm{Q}_{\mathrm{i}}$ & $\mathrm{m}^{3} \mathrm{~s}^{-1}$ & Measured stream discharge \\
\hline $\mathrm{Q}_{\mathrm{c}}$ & $\mathrm{m}^{3} \mathrm{~s}^{-1}$ & Estimated stream discharge from a rating curve \\
\hline $\mathrm{W}$ & $\mathrm{m}$ & Width \\
\hline $\mathrm{d}$ & $\mathrm{m}$ & Depth \\
\hline $\mathrm{V}$ & $\mathrm{ms}^{-1}$ & Velocity \\
\hline$\alpha$ & $\mathrm{m}$ & Datum correction (stage at zero flow) \\
\hline$\beta$ & - & Constant (exponent in the rating curve equation) \\
\hline $\mathrm{p}$ & - & Constant (coefficient multiplying stage in the rating curve equation) \\
\hline $\mathrm{a}$ & - & Width hydraulic geometry coefficient \\
\hline $\mathrm{c}$ & - & Depth hydraulic geometry coefficient \\
\hline $\mathrm{k}$ & - & Velocity hydraulic geometry coefficient \\
\hline $\mathrm{b}$ & - & Width hydraulic geometry exponent \\
\hline $\mathrm{f}$ & - & Depth hydraulic geometry exponent \\
\hline $\mathrm{m}$ & - & Velocity hydraulic geometry exponent \\
\hline $\mathrm{N}$ & - & number of data points in a sample \\
\hline $\mathrm{n}$ & - & number of discharge measurements \\
\hline $\mathrm{M}$ & - & number of verticals \\
\hline $\mathrm{K}$ & - & coverage factor $(\mathrm{k}=2$ for $95 \%$ C.I $)$ \\
\hline $\mathrm{t}$ & - & Student's t correction (for $95 \%$ confidence $\mathrm{t}=2$ ) \\
\hline $\mathrm{u}_{\mathrm{m}}$ & $\%$ & Uncertainty in determination of mean velocity for number of verticals \\
\hline $\mathrm{u}_{\mathrm{s}}$ & $\%$ & Uncertainty due to calibration errors \\
\hline $\mathrm{u}_{\mathrm{b}}$ & $\%$ & Uncertainty in width \\
\hline $\mathrm{u}_{\mathrm{d}}$ & $\%$ & Uncertainty in depth \\
\hline $\mathrm{u}_{\mathrm{p}}$ & $\%$ & Uncertainty in determination of mean velocity for number of points in the vertical \\
\hline $\mathrm{u}_{\mathrm{c}}$ & $\%$ & Uncertainty in determination of mean velocity for current meter rating \\
\hline $\mathrm{u}_{\mathrm{e}}$ & $\%$ & Uncertainty in determination of mean velocity for time of exposure \\
\hline $\mathrm{U}_{\mathrm{RC}}$ & $\%$ & Uncertainty of hourly stream discharge due to the rating curve \\
\hline $\mathrm{U}_{\mathrm{me}}$ & $\%$ & uncertainty due to measurement errors \\
\hline $\mathrm{U}_{\text {in }}$ & $\%$ & uncertainty due to streambed incision \\
\hline$\overline{X_{\mathrm{dm}}}$ & $\%$ & uncertainty in the daily mean discharge \\
\hline $\mathrm{S}_{\mathrm{e}}$ & $\%$ & standard error of estimate \\
\hline $\mathrm{S}_{\mathrm{mr}}$ & $\%$ & standard error of mean \\
\hline $\mathrm{S}_{\mathrm{wl}}$ & $\%$ & standard error of log of water level measurement \\
\hline
\end{tabular}

415 Using Equation $\mathrm{A} 1$ and literature values for the seven measurement errors (Table A2), we find $\mathrm{U}_{\mathrm{me}}=10.8 \%$.

The uncertainty in hourly stream discharge due to the rating curve was determined with a statistical method by calculating the standard error of estimate, $S_{e}$, where the quadratic rating curve was linearized with a logarithmic transformation following Herschy (1994): 
$S_{e}= \pm t \sqrt{\frac{\sum_{i=1}^{n}\left(\ln Q_{i}-\ln Q_{c}\right)^{2}}{n-2}}$

420 where $\mathrm{t}$ is Student's $\mathrm{t}$ correction (for 95\% confidence $\mathrm{t}=2$ ), $\mathrm{n}$ is number of discharge measurements, $\mathrm{Q}_{\mathrm{i}}$ is discharge measured, and $\mathrm{Q}_{\mathrm{c}}$ is discharge estimated using a rating curve.

Table A2: Standard uncertainties in a single measurement of stream discharge due to seven measurement errors, using values from WMO (2010). Please refer to Table A1 for Nomenclature.

\begin{tabular}{|c|l|}
\hline Uncertainties & Values used in this study \\
\hline $\mathrm{u}_{\mathrm{m}}$ & $4.5 \%$ for a minimum of 10 verticals \\
\hline $\mathrm{u}_{\mathrm{s}}$ & $1 \%$ \\
\hline $\mathrm{u}_{\mathrm{b}}$ & $0.15 \%$ (for width range $0-100 \mathrm{~m}$ ) \\
\hline $\mathrm{u}_{\mathrm{d}}$ & $0.65 \%$ (for depth range $0.4-6 \mathrm{~m}$ ) \\
\hline $\mathrm{u}_{\mathrm{p}}$ & $7.5 \%$ (number of verticals $=1$ ) \\
\hline $\mathrm{u}_{\mathrm{c}}$ & $1 \%$ (for average velocity of around $0.25 \mathrm{~ms}^{-1}$ \\
\hline $\mathrm{u}_{\mathrm{e}}$ & $4 \%$ (for time of exposure between $30-60 \mathrm{~s}$ ) \\
\hline $\mathrm{M}$ & 10 (number of verticals varied between $10-16$ \\
\hline $\mathrm{K}$ & 2 for $95 \%$ C.I \\
\hline
\end{tabular}

425 Using Equation A2, the uncertainty of hourly stream discharge due to the rating curve, $\mathrm{U}_{\mathrm{RC}}$ is calculated to $17 \%$.

Lastly, the uncertainty in daily mean discharge due to the averaging of hourly data is estimated in two steps using the methodology of Dymond and Christain (1982). First, $S_{\mathrm{mr}}$, the standard error of the daily mean, is calculated using a logarithmic transformation of discharge, $\mathrm{Q}$ from Equation 1, in order to make it a linear relation:

$S_{m r}= \pm t S_{e}\left(\frac{1}{N}+\frac{(\ln (\mathrm{h}+\alpha)-\overline{\ln (\mathrm{h}+\alpha)})^{2}}{\sum(\ln (\mathrm{h}+\alpha)-\overline{\ln (\mathrm{h}+\alpha)})^{2}}\right)^{1 / 2}$

430 where, $\mathrm{N}$ is the number of data points in the sample (here, 24 samples in a day). Second, $\mathrm{X}_{\mathrm{dm}}$ is uncertainty in the daily mean discharge is calculated as:

$X_{d m}=\frac{1}{N} \sum_{i=1}^{N} \sqrt{S_{m r}^{2}+\beta^{2} S_{w l}^{2}} Q_{i}$

where, $S_{\mathrm{wl}}$ is the standard error of log of water level measurement (calculated using Equation A2). Using Equation A3 and $\mathrm{A} 4$, the uncertainty in the daily mean discharge, $\mathrm{X}_{\mathrm{dm}}$ is calculated to $25 \%$. All uncertainties are expressed as the $95 \%$

435 confidence level.

\section{Author contribution statement}

RM performed data analysis and wrote the manuscript with support from AR. RM and AR conceived and planned the study. SL and MC did the majority of field data collection, with support from RM, AR, and SC. DvA performed surface energy balance modeling. All authors discussed the results and contributed to the final manuscript. 
https://doi.org/10.5194/tc-2020-314

Preprint. Discussion started: 27 November 2020

(c) Author(s) 2020. CC BY 4.0 License.

(c) (i)

\section{Acknowledgements}

We are thankful for the support of Polar Field Services and the Rutgers Geography Department. Funding for this work comes from the NASA Cryosphere program (Award\# 80NSSC19K0942 and \#NNX14AH93G). SL was funded by the NSF Graduate Research Fellowship Program. QGIS was used to prepare maps. Polar Geospatial Center's Arctic DEMs were used in this study. Thank you to Kyle Mattingly, Jing Xiao, and Isatis Cintron for constructive feedback on the manuscript.

\section{Data availability}

KAN_L weather station data from the Programme for Monitoring of the Greenland Ice Sheet (PROMICE) and the Greenland Analogue Project (GAP) were provided by the Geological Survey of Denmark and Greenland (GEUS) at http://www.promice.dk. All other data will be available at the PANGEA repository (in the meanwhile this data is made available to the reviewers as supplementary material).

\section{Competing interests}

The authors declare that they have no conflicts of interest.

\section{References}

455 Andreadis, K. M., Brinkerhoff, C. B. and Gleason, C. J.: Constraining the assimilation of SWOT observations with hydraulic geometry relations, Water Resour. Res., 56(5), 1-21, doi:10.1029/2019WR026611, 2020.

Andrews, L. C., Catania, G. A., Hoffman, M. J., Gulley, J. D., Lüthi, M. P., Ryser, C., Hawley, R. L. and Neumann, T. A.: Direct observations of evolving subglacial drainage beneath the Greenland Ice Sheet, Nature, 514(7520), 80-83, doi:10.1038/nature13796, 2014.

460 Ashmore, P. and Sauks, E.: Prediction of discharge from water surface width in a braided river with implications for at-astation hydraulic geometry, Water Resour. Res., 42(3), 1-11, doi:10.1029/2005WR003993, 2006.

Bartholomew, I., Nienow, P., Sole, A., Mair, D., Cowton, T. and King, M. A.: Short-term variability in Greenland Ice Sheet motion forced by time-varying meltwater drainage: Implications for the relationship between subglacial drainage system behavior and ice velocity, J. Geophys. Res. Earth Surf., 117, 1-17, doi:10.1029/2011JF002220, 2012.

465 Bell, R. E., Chu, W., Kingslake, J., Das, I., Tedesco, M., Tinto, K. J., Zappa, C. J., Frezzotti, M., Boghosian, A. and Lee, W. S.: Antarctic ice shelf potentially stabilized by export of meltwater in surface river, Nature, 544(7650), 344-348, doi:10.1038/nature22048, 2017. 
https://doi.org/10.5194/tc-2020-314

Preprint. Discussion started: 27 November 2020

(c) Author(s) 2020. CC BY 4.0 License.

\section{(c) (i)}

Bennartz, R., Shupe, M. D., Turner, D. D., Walden, V. P., Steffen, K., Cox, C. J., Kulie, M. S., Miller, N. B. and Pettersen, C.: July 2012 Greenland melt extent enhanced by low-level liquid clouds, Nature, 496(7443), 83-86, doi:10.1038/nature12002, 2013.

Chandler, D. M., Wadham, J. L., Lis, G. P., Cowton, T., Sole, A., Bartholomew, I., Telling, J., Nienow, P., Bagshaw, E. B., Mair, D., Vinen, S. and Hubbard, A.: Evolution of the subglacial drainage system beneath the Greenland Ice Sheet revealed by tracers, Nat. Geosci., 6(3), 195-198, doi:10.1038/ngeo1737, 2013.

Chen, X., Zhang, X., Church, J. A., Watson, C. S., King, M. A., Monselesan, D., Legresy, B. and Harig, C.: The increasing rate of global mean sea-level rise during 1993 - 2014, Nat. Clim. Chang., 7(July), 492-495, doi:10.1038/nclimate3325, 2017. Chow, V. T.: Handbook of Applied Hydrology: A Compendium of Water-Resources Technology, McGraw-Hill Company, New York., 1964.

Chu, V. W.: Greenland ice sheet hydrology: A review, Prog. Phys. Geogr., 38(1), 19-54, 2014.

Colgan, W., Steffen, K., McLamb, W. S., Abdalati, W., Rajaram, H., Motyka, R., Phillips, T. and Anderson, R.: An increase 480 in crevasse extent, West Greenland: Hydrologic implications, Geophys. Res. Lett., 38(18), 1-7, doi:10.1029/2011GL048491, 2011.

Cook, J. M., Hodson, A. J. and Irvine-Fynn, T. D. L.: Supraglacial weathering crust dynamics inferred from cryoconite hole hydrology, Hydrol. Process., 30(3), 433-446, doi:10.1002/hyp.10602, 2016.

Cooper, M. G., Smith, L. C., Rennermalm, A. K., Mige, C., Pitcher, L. H., Ryan, J. C., Yang, K. and Cooley, S. W.: Meltwater storage in low-density near-surface bare ice in the Greenland ice sheet ablation zone, Cryosphere, 12(3), 955-970, doi:10.5194/tc-12-955-2018, 2018.

Cullather, R. I., Nowicki, S. M. J., Zhao, B. and Koenig, L. S.: A characterization of Greenland ice sheet surface melt and runoff in contemporary reanalyses and a regional climate model, Front. Earth Sci., 4, 1-20, doi:10.3389/feart.2016.00010, 2016.

490 Das, S. B., Joughin, I., Behn, M. D., Howat, I. M., King, M. A., Lizarralde, D. and Bhatia, M. P.: Fracture propagation to the base of the Greenland ice sheet during supraglacial lake drainage, Science, 320(5877), 778-781, doi:10.1126/science.1153360, 2008.

Dymond, J. R. and Christian, R.: Accuracy of discharge determined from a rating curve, Hydrol. Sci. J., 27(4), 493-504, doi:10.1080/02626668209491128, 1982.

495 Fausto, R. S.: The implication of nonradiative energy fluxes dominating Greenland ice sheet exceptional ablation area surface melt in 2012, Geophys. Res. Lett., 43, 2649-2658, doi:10.1002/2016GL067720, 2016.

Ferguson, R. I.: Hydraulics and hydraulic geometry, Prog. Phys. Geogr., 10, 1-31, 1986.

Fettweis, X., Box, J. E., Agosta, C., Amory, C., Kittel, C., Lang, C., Van As, D., Machguth, H. and Gallée, H.: Reconstruction s of the 1900-2015 Greenland ice sheet surface mass balance using the regional climate MAR model, Cryosphere, 11(2), 10151033, doi:10.5194/tc-11-1015-2017, 2017. 
https://doi.org/10.5194/tc-2020-314

Preprint. Discussion started: 27 November 2020

(c) Author(s) 2020. CC BY 4.0 License.

(c) (i)

Flowers, G. E.: Hydrology and the future of the Greenland Ice Sheet, Nat. Commun., 9(1), 1-4, doi:10.1038/s41467-01805002-0, 2018.

Gallagher, M. R., Chepfer, H., Shupe, M. D. and Guzman, R.: Warm temperature extremes across Greenland connected to clouds, Geophys. Res. Lett., 47(9), 1-10, doi:10.1029/2019GL086059, 2020.

505 Gleason, C. J.: Hydraulic geometry of natural rivers: A review and future directions, Prog. Phys. Geogr., 39(3), 337-360, doi:10.1177/0309133314567584, 2015.

Gleason, C. J., Smith, L. C., Chu, V. W., Legleiter, C. J., Pitcher, L. H., Overstreet, B. T., Rennermalm, A. K., Forster, R. R. and Yang, K.: Characterizing supraglacial meltwater channel hydraulics on the Greenland Ice Sheet from in situ observations, Earth Surf. Process. Landforms, 41(14), 2111-2122, doi:10.1002/esp.3977, 2016.

510 Herschy, R. W.: The uncertainty in a current meter measurement, Flow Meas. Instrum., 13(5-6), 281-284, doi:10.1016/S09555986(02)00047-X, 2002.

Herschy, R.: The stage-discharge relation, Flow Meas. Instrum., 4(1), 11-15, 1993.

Herschy, R.: The velocity-area method, Flow Meas. Instrum., 4(1), 7-10, doi:10.1016/0955-5986(93)90004-3, 1993.

Herschy, R.: The analysis of uncertainties in the stage-discharge relation, Flow Meas. Instrum., 5(3), 188-190, 515 doi:10.1016/0955-5986(94)90018-3, 1994.

Hewitt, I. J.: Seasonal changes in ice sheet motion due to melt water lubrication, Earth Planet. Sci. Lett., 371-372, 16-25, doi:10.1016/j.eps1.2013.04.022, 2013.

Hofer, S., Tedstone, A. J., Fettweis, X. and Bamber, J. L.: Decreasing cloud cover drives the recent mass loss on the Greenland Ice Sheet, Sci. Adv., 3(6), doi:10.1126/sciadv.1700584, 2017.

520 Hoffman, M. J., Catania, G. A., Neumann, T. A., Andrews, L. C. and Rumrill, J. A.: Links between acceleration, melting, and supraglacial lake drainage of the western Greenland Ice Sheet, J. Geophys. Res. Earth Surf., 116(4), 1-16, doi:10.1029/2010JF001934, 2011.

Holmes, G. W.: Morphology and hydrology of the Mint Julep area, southwest Greenland. In Project Mint Julep: Investigation of Smooth Ice Areas of the Greenland Ice Cap, 1953; Part II: Special Scientific Reports., 1-50, 1955.

525 Izeboud, M., Lhermitte, S., Van Tricht, K., Lenaerts, J. T. M., Van Lipzig, N. P. M. and Wever, N.: The spatiotemporal variability of cloud radiative effects on the Greenland Ice Sheet surface mass balance, Geophys. Res. Lett., 47(12), 1-9, doi:10.1029/2020GL087315, 2020.

Karlstrom, L., Zok, A. and Manga, M.: Near-surface permeability in a supraglacial drainage basin on the Llewellyn Glacier, Juneau Icefield, British Columbia, Cryosphere, 8(2), 537-546, doi:10.5194/tc-8-537-2014, 2014.

530 Kingslake, J., Ely, J. C., Das, I. and Bell, R. E.: Widespread movement of meltwater onto and across Antarctic ice shelves, Nature, 544(7650), 349-352, doi:10.1038/nature22049, 2017.

Knighton, A. D.: Channel form and flow characteristics of supraglacial streams, Austre Okstindbreen, Norway, Arct. Alp. Res., 13(3), 295, doi:10.2307/1551036, 1981. 
https://doi.org/10.5194/tc-2020-314

Preprint. Discussion started: 27 November 2020

(c) Author(s) 2020. CC BY 4.0 License.

\section{(c) (i)}

Lampkin, D. J. and VanderBerg, J.: Supraglacial melt channel networks in the Jakobshavn Isbræ region during the 2007 melt season, Hydrol. Process., 28, 6038-6053, doi:10.1002/hyp.10085, 2014.

Leopold, L. and Maddock, T.: The hydraulic geometry of stream channels and some physiographic implications, US Government Printing Office., 1953.

Marston, R. A.: Supraglacial stream dynamics on the Juneau Icefield, Ann. Assoc. Am. Geogr., 73(4), 597-608, doi:10.1111/j.1467-8306.1983.tb01861.x, 1983.

540 Mattingly, K. S., Mote, T. L. and Fettweis, X.: Atmospheric river impacts on Greenland Ice Sheet surface mass balance, J. Geophys. Res. Atmos., 123(16), 8538-8560, doi:10.1029/2018JD028714, 2018.

McGrath, D., Colgan, W., Steffen, K., Lauffenburger, P. and Balog, J.: Assessing the summer water budget of a moulin basin in the sermeq avannarleq ablation region, Greenland ice sheet, J. Glaciol., 57(205), 954-964, doi:10.3189/002214311798043735, 2011.

545 Mernild, S. H., Hasholt, B. and Liston, G. E.: Water flow through Mittivakkat Glacier, Ammassalik Island, SE Greenland, Geogr. Tidsskr., 106(1), 25-43, doi:10.1080/00167223.2006.10649543, 2006.

Mernild, S. H., Liston, G. E., van As, D., Hasholt, B. and Yde, J. C.: High-resolution ice sheet surface mass-balance and spatiotemporal runoff simulations: Kangerlussuaq, west Greenland, Arctic, Antarct. Alp. Res., 50(1), doi:10.1080/15230430.2017.1415856, 2018.

550 Mouginot, J., Rignot, E., Bjørk, A. A., van den Broeke, M., Millan, R., Morlighem, M., Noël, B., Scheuchl, B. and Wood, M.: Forty-six years of Greenland Ice Sheet mass balance from 1972 to 2018, Proc. Natl. Acad. Sci. U. S. A., 116(19), 9239-9244, doi:10.1073/pnas.1904242116, 2019.

Moustafa, S. E., Rennermalm, A. K., Smith, L. C., Miller, M. A., Mioduszewski, J. R., Koenig, L. S., Hom, M. G. and Shuman, C. A.: Multi-modal albedo distributions in the ablation area of the southwestern Greenland Ice Sheet, Cryosphere, 9(3), 905555 923, doi:10.5194/tc-9-905-2015, 2015.

Munro, D. S.: Delays of supraglacial runoff from differently defined microbasin areas on the Peyto Glacier, Hydrol. Process., 25(19), 2983-2994, doi:10.1002/hyp.8124, 2011.

Noël, B., Van De Berg, W. J., Van Wessem, J. M., Van Meijgaard, E., Van As, Di., Lenaerts, J. T. M., Lhermitte, S., Munneke, P. K., Smeets, C. J. P. P., Van Ulft, L. H., Van De Wal, R. S. W. and Van Den Broeke, M. R.: Modelling the climate and

560 surface mass balance of polar ice sheets using RACMO2 - Part 1: Greenland (1958-2016), Cryosphere, 12(3), 811-831, doi:10.5194/tc-12-811-2018, 2018.

Pitcher, L. H. and Smith, L. C.: Supraglacial streams and rivers, Annu. Rev. Earth Planet. Sci., 421-452, doi:10.1146/annurevearth-053018-060212, 2019.

Rennermalm, a K., Moustafa, S. E., Mioduszewski, J., Chu, V. W., Forster, R. R., Hagedorn, B., Harper, J. T., Mote, T. L.,

565 Robinson, D. a, Shuman, C. a, Smith, L. C. and Tedesco, M.: Understanding Greenland ice sheet hydrology using an integrated multi-scale approach, Environ. Res. Lett., 8(1), 015017, doi:10.1088/1748-9326/8/1/015017, 2013. 
https://doi.org/10.5194/tc-2020-314

Preprint. Discussion started: 27 November 2020

(c) Author(s) 2020. CC BY 4.0 License.

Ryan, J. C., Smith, L. C., Van As, D., Cooley, S. W., Cooper, M. G., Pitcher, L. H. and Hubbard, A.: Greenland Ice Sheet surface melt amplified by snowline migration and bare ice exposure, Sci. Adv., 5(3), 1-11, doi:10.1126/sciadv.aav3738, 2019. Schoof, C.: Ice-sheet acceleration driven by melt supply variability, Nature, 468(7325), 803-806, doi:10.1038/nature09618, 2010.

Shepherd, A., Hubbard, A., Nienow, P., King, M. A., McMillan, M. and Joughin, I.: Greenland ice sheet motion coupled with daily melting in late summer, Geophys. Res. Lett., 36(1), 2-5, doi:10.1029/2008GL035758, 2009.

Shepherd, A., Ivins, E., Rignot, E., Smith, B., van den Broeke, M., Velicogna, I., Whitehouse, P., Briggs, K., Joughin, I., Krinner, G., Nowicki, S., Payne, T., Scambos, T., Schlegel, N., A, G., Agosta, C., Ahlstrøm, A., Babonis, G., Barletta, V. R., Bjørk, A. A., Blazquez, A., Bonin, J., Colgan, W., Csatho, B., Cullather, R., Engdahl, M. E., Felikson, D., Fettweis, X., Forsberg, R., Hogg, A. E., Gallee, H., Gardner, A., Gilbert, L., Gourmelen, N., Groh, A., Gunter, B., Hanna, E., Harig, C., Helm, V., Horvath, A., Horwath, M., Khan, S., Kjeldsen, K. K., Konrad, H., Langen, P. L., Lecavalier, B., Loomis, B., Luthcke, S., McMillan, M., Melini, D., Mernild, S., Mohajerani, Y., Moore, P., Mottram, R., Mouginot, J., Moyano, G., Muir, A., Nagler, T., Nield, G., Nilsson, J., Noël, B., Otosaka, I., Pattle, M. E., Peltier, W. R., Pie, N., Rietbroek, R., Rott, H., Sandberg Sørensen, L., Sasgen, I., Save, H., Scheuchl, B., Schrama, E., Schröder, L., Seo, K. W., Simonsen, S. B., Slater, T., Spada, G., Sutterley, T., Talpe, M., Tarasov, L., van de Berg, W. J., van der Wal, W., van Wessem, M., Vishwakarma, B. D., Wiese, D., Wilton, D., Wagner, T., Wouters, B. and Wuite, J.: Mass balance of the Greenland Ice Sheet from 1992 to 2018, Nature, 579(7798), 233-239, doi:10.1038/s41586-019-1855-2, 2019.

Smith, L. C., Chu, V. W., Yang, K., Gleason, C. J., Pitcher, L. H., Rennermalm, A. K., Legleiter, C. J., Behar, A. E., Overstreet, 585 B. T., Moustafa, S. E., Tedesco, M., Forster, R. R., LeWinter, A. L., Finnegan, D. C., Sheng, Y. and Balog, J.: Efficient meltwater drainage through supraglacial streams and rivers on the southwest Greenland ice sheet, Proc. Natl. Acad. Sci., 112(4), 1001-1006, doi:10.1073/pnas.1413024112, 2015.

Smith, L. C., Yang, K., Pitcher, L. H., Overstreet, B. T., Chu, V. W., Rennermalm, Å. K., Ryan, J. C., Cooper, M. G., Gleason, C. J., Tedesco, M., Jeyaratnam, J., van As, D., van den Broeke, M. R., van de Berg, W. J., Noël, B., Langen, P. L., Cullather,

590 R. I., Zhao, B., Willis, M. J., Hubbard, A., Box, J. E., Jenner, B. a. and Behar, A. E.: Direct measurements of meltwater runoff on the Greenland ice sheet surface, Proc. Natl. Acad. Sci., 114(50), E10622-31, doi:10.1073/pnas.1707743114, 2017.

Smith, L. C., Andrews, C. A., Pitcher, L. H., Overstreet, B. T., Rennermalm, Å. K., Cooper, M. G., Cooley, S. W., Ryan, J. C., Miège, C., Kershner, C., Simpson, C. E.: Supraglacial meltwater forcing of subglacial water storage and diurnal ice sheet motion, (Submitted), 2020.

595 Solinst Canada Ltd.: Solinst 3001 levelogger series user guide, 1-85 [online] Available from: https://www.solinst.com/products/dataloggers-and-telemetry/3001-levelogger-series/operating-instructions/user-guide/3001user-guide.pdf, 2020.

Takeuchi, N., Koshima, S., Yoshimura, Y., Seko, K. and Fujita, K.: Characteristics of cryoconite holes on a Himalayan glacier, Yala Glacier Central Nepal, Bull. Glaciol. Res., 17, 51-59, 2000. 
https://doi.org/10.5194/tc-2020-314

Preprint. Discussion started: 27 November 2020

(c) Author(s) 2020. CC BY 4.0 License.

(c) (i)

600 Taylor, J.: Introduction to error analysis, the study of uncertainties in physical measurements, University Science Books, Sausalito, California., 1997.

van As, D. and Fausto, R. S.: Programme for Monitoring of the Greenland Ice Sheet (PROMICE): First temperature and ablation records, Geol. Surv. Denmark Greenl. Bull., (23), 73-76, doi:10.34194/geusb.v23.4876, 2011.

van As, D.: Warming, glacier melt and surface energy budget from weather station observations in the melville bay region of northwest greenland, J. Glaciol., 57(202), 208-220, doi:10.3189/002214311796405898, 2011.

van As, D., Hubbard, A. L., Hasholt, B., Mikkelsen, A. B., Van Den Broeke, M. R. and Fausto, R. S.: Large surface meltwater discharge from the Kangerlussuaq sector of the Greenland ice sheet during the record-warm year 2010 explained by detailed energy balance observations, Cryosphere, 6(1), 199-209, doi:10.5194/tc-6-199-2012, 2012.

van As, D., Hasholt, B., Ahlstrøm, A. P., Box, J. E., Cappelen, J., Colgan, W., Fausto, R. S., Mernild, S. H., Mikkelsen, A. B.,

610 Noël, B. P. Y., Petersen, D. and van den Broeke, M. R.: Reconstructing Greenland Ice Sheet meltwater discharge through the Watson River (1949-2017), Arctic, Antarct. Alp. Res., 50(1), doi:10.1080/15230430.2018.1433799, 2018.

van de Wal, R. S. W., Boot, W., van den Broeke, M. R., Smeets, C. J. P. P., Reijmer, C. H., Donker, J. J. A. and Oerlemans, J.: Large and Rapid Melt-Induced Velocity Changes in the Ablation Zone of the Greenland Ice Sheet, Science, 321(5885), 111-113, doi:10.1126/science.1158540, 2008.

615 van den Broeke, M. R., Smeets, C. J. P. P. and Wal, R. S. W. Van De: The seasonal cycle and interannual variability of surface energy balance and melt in the ablation zone of the west Greenland ice sheet, Cryosphere, 5, 377-390, doi:10.5194/tc-5-377$2011,2011$.

van den Broeke, M., Enderlin, E., Howat, I., Kuipers Munneke, P., Noël, B., van de Berg, W. J., van Meijgaard, E. and Wouters, B.: On the recent contribution of the Greenland ice sheet to sea level change, Cryosphere, 10, 1933-1946, doi:10.5194/tc-10620 1933-2016, 2016.

van den Broeke, M., Smeets, P., Ettema, J. and Munneke, P. K.: Surface radiation balance in the ablation zone of the west Greenland ice sheet, J. Geophys. Res., 113(D13105), 1-14 doi:10.1029/2007JD009283, 2008.

Van Tricht, K., Lhermitte, S., Lenaerts, J. T. M., Gorodetskaya, I. V., L’Ecuyer, T. S., Noël, B., Van Den Broeke, M. R., Turner, D. D. and Van Lipzig, N. P. M.: Clouds enhance Greenland ice sheet meltwater runoff, Nat. Commun., 7(1), 1-9, 625 doi:10.1038/ncomms10266, 2016.

Velicogna, I., Mohajerani, Y., Geruo, A., Landerer, F., Mouginot, J., Noel, B., Rignot, E., Sutterley, T., van den Broeke, M., van Wessem, M. and Wiese, D.: Continuity of ice sheet mass loss in Greenland and Antarctica from the GRACE and GRACE follow-on missions, Geophys. Res. Lett., 47(8), 1-8, doi:10.1029/2020GL087291, 2020.

Yang, K. and Smith, L. C.: Supraglacial streams on the greenland ice sheet delineated from combined spectral-shape 630 information in high-resolution satellite imagery, IEEE Geosci. Remote Sens. Lett., 10(4), 801-805, doi:10.1109/LGRS.2012.2224316, 2013.

Yang, K. and Smith, L. C.: Internally drained catchments dominate supraglacial hydrology of the southwest Greenland Ice Sheet, J. Geophys. Res. Earth Surf., 121, 1891-1910, doi:10.1002/ 2016JF003927, 2016. 
https://doi.org/10.5194/tc-2020-314

Preprint. Discussion started: 27 November 2020

(C) Author(s) 2020. CC BY 4.0 License.

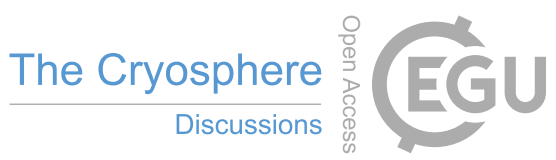

Yang, K., Smith, L. C., Karlstrom, L., Cooper, M. G., Tedesco, M., Van As, D., Cheng, X., Chen, Z. and Li, M.: A new surface

635 meltwater routing model for use on the Greenland Ice Sheet surface, Cryosphere, 12(12), 3791-3811, doi:10.5194/tc-12-37912018, 2018. 